\title{
Influence of salinity stress on bacterial diversity from a marine bioinvasion perspective: evaluation through microcosm experiments
}

\author{
Nishanth Kuchi ${ }^{1,2}$ and Lidita Khandeparker ${ }^{1, *}$ \\ ${ }^{1}$ CSIR-National Institute of Oceanography, Dona Paula, Goa 403 004, India \\ ${ }^{2}$ School of Earth, Ocean and Atmospheric Sciences, Goa University, Taleigao, Goa 403 206, India
}

Mid-ocean ballast water exchange has been used since the past few years to control bioinvasion through ballast water (BW), which requires the ship to exchange part of its $B W$ in the open ocean. The change in salinity is expected to be detrimental to coastal species. This study evaluates the changes in bacterial diversity with respect to salinity stress when translocated into an environment with non-ambient salinity. Surface water samples from three coastal ports, namely hypersaline Kandla port in Gujarat, saline Paradip port in Odisha, and freshwater Kolkata port in West Bengal, India were collected and aged in dark for 30 days to mimic BW tank conditions. The aged water samples were translocated into water collected from the estuarine mouth (Dona Paula), midestuary (Cortalim) and upstream location (Sanvordem) of Zuari Estuary, Goa and incubated in the laboratory. Quantitative polymerase chain reaction technique was used to assess major bacterial phyla. Culturable marine bacteria and Vibrio spp., including $\gamma$-proteobacteria preferred higher salinity, whereas culturable freshwater bacteria, including coliforms in conjunction with $\alpha$-, $\beta$-proteobacteria, Bacteroidetes and Firmicutes preferred lower salinity. The freshwater port bacteria could withstand salinity stress better than those from the hypersaline or saline ports. The species comprising these phyla could be regionand niche-specific. The invasive potential of these bacterial clades would depend on the environmental suitability of the recipient port. Studying the changes in the ecosystem of the port environment after BW discharge in real-time would provide meaningful insights into the invasive potential of these bacterial phyla.

Keywords: Bacterial community, ballast water exchange, marine bioinvasion, salinity stress, microcosm experiment.

OCEANIC transport accounts for more than $90 \%$ of the world's cargo and in addition to the intended cargo, the translocation of over 10 billion tonnes of ballast water

*For correspondence. (e-mail: klidita@nio.org)
(BW) also occurs annually ${ }^{1}$. As a result, a plethora of organisms present in the BW are introduced into nonnative environments ${ }^{2}$, which is estimated to be about 7000 living species ${ }^{3}$. Such introduction of alien organisms into a non-indigenous environment is termed as 'bioinvasion' and BW is considered to be one of the key vectors for marine bioinvasion. When introduced into a non-native environment, the impact of bioinvasion may result in changing the biodiversity thereby altering the food web, and can have a direct impact on the socioeconomic and human health ${ }^{2,4}$. Marine bioinvasion through ships' ballast tanks has been recognized as one of the greatest threats to the oceans.

Many studies have reported a profusion of invasive organisms in the past few decades ${ }^{5-7}$. Microorganisms are spread in higher numbers than other macroorganisms given their abundance in any given ecosystem ${ }^{8-10}$. Additionally, BW tanks act as incubators for heterotrophic bacteria which can withstand prolonged dark conditions, unlike other autotrophs ${ }^{11}$. Thus, by virtue of their abundance, life-history characteristics and potential pathogenicity or toxicity, bacteria possess a great capacity to invade and cause detrimental effects in new environments $^{12}$. Hence the threat of bacterial invaders is a major concern when compared to other higher organisms. Specifically, the spreading of bacteria, including pathogenic strains on a global level through ships' BW is a phenomenon that is gaining increased importance ${ }^{13}$. Vibrio cholerae, which is the causative agent for cholera, can be transported via ships' BW and has caused epidemics in areas where it was not reported earlier ${ }^{13-16}$.

The International Maritime Organization (IMO) has put forth guidelines to reduce the risk of bioinvasion through ships' BW. Mid-ocean ballast water exchange (BWE) requires ships to exchange a percentage of coastal water with open ocean water (200 nautical miles from the coast). The idea is to release the organisms into an environment with non-ambient salinity to reduce the undesirable bacterial load in exchange for oceanic species with presumably lesser concern ${ }^{17}$. A study has reported that salinity is the most significant environmental factor that 
contributes to the bacterial diversity in $\mathrm{BW}$ tanks ${ }^{18}$. Hence, oceanic species are less likely to survive under environmental stress when released into coastal (marine or freshwater) environments ${ }^{19}$. Many studies have assessed the efficiency of BWE with respect to phytoplankton abundance ${ }^{20}$, marine invertebrates ${ }^{21}$, zooplankton abundance $^{22}$, diatoms and dinoflagellates ${ }^{23}$, and virus-like particles $^{24}$. The importance of bacterial invaders has taken precedence more recently. Studies have reported that bacterial abundances did not change significantly in most of the cases after BWE and at the end of a voyage ${ }^{25,26}$. In contrast, studies on bacterial diversity during a voyage reported a marked change in the community due to $\mathrm{BWE}^{27}$, and stressed that $\mathrm{BW}$ tanks act as incubators for the prevailing bacteria which changed over time during transit ${ }^{28}$. Moreover, it has been reported that the response of bacterial populations to changing salinity is unlike higher organisms ${ }^{29}$. A study on both the culturable and unculturable segments of bacteria showed that although the abundance of culturable bacteria in ballast tanks remained unchanged during a voyage, there was significant decrease in the unculturable bacteria and their density gradient gel electrophoresis (DGGE) profiles were different after $\mathrm{BWE}^{30}$. Bacterial diversity is evershifting as a response to environmental stress. Rather than relying on the variation in individual abundances which may not equate to significant shifts in the bacterial community, a community-level approach would provide a more sensitive and meaningful understanding of their response.

The premise of BWE is to expose the coastal bacterial communities in the BW tanks to a non-ambient salinity (open ocean). But the assumption that salinity change plays an important role in reducing bacterial load during BWE is not yet fully explored and explained. Although bacterial diversity is heavily influenced by the prevailing environmental conditions ${ }^{31}$, studies concentrating on the response of bacterial populations to changing environmental conditions are sparse. Some studies have reported the importance of salinity in the virility and viability of pathogens like toxicogenic $V$. cholerae $^{32}$. But there is a paucity of knowledge on the influence of salinity as a major environmental factor in the context of BWE. In view of this, the objective of the present study was to understand the response of bacterial communities to changes in salinity using microcosm experiments. Surface-water samples from coastal ports with varied salinity conditions (hypersaline, saline and freshwater) were collected, aged and translocated into water collected from different areas (salinity gradient) of an estuary. This incubation experiment allowed us to assess the response of bacteria from different environments to a sudden salinity change, which is analogous to the release of BW by ships into non-indigenous environments.

Real-time quantitative polymerase chain reaction (qPCR) was used to assess the contribution of major bac- terial phyla (Proteobacteria subclasses $(\alpha, \beta$ and $\gamma)$, Bacteroidetes, Firmicutes and Actinobacteria) to bacterial diversity. The variation in culturable pathogenic abundance was also assessed using standard plating techniques. Since dark conditions would have immensely reduced the photosynthetic bacteria, we hypothesized that bacterial diversity would be mostly heterotrophic and expected to change significantly as a response to salinity shock after translocation. Extreme salinity shock is expected when bacteria from the hypersaline port are translocated into freshwater from the estuary and vice-versa with the freshwater port bacteria. The ability of various bacterial clades to tackle salinity stress would depend on the mechanisms they adopt to cope with this stress.

\section{Materials and methods}

\section{Sampling strategy}

Surface-water samples were collected from Kandla port, Gujarat, India (Local Fishing Craft Anchorage-2; $\left.23^{\circ} 01^{\prime} 03^{\prime \prime} \mathrm{N}, 70^{\circ} 13^{\prime} 19^{\prime \prime} \mathrm{E}\right)$ for the hypersaline water experiment (experiment I; salinity 39.68) using a 51 sampler (Niskin) and transferred into a 501 carboy (Nalgene) and stored in dark, static condition for 30 days to simulate the ballast tank condition. For translocation into water with varying salinities, surface water samples were collected from the Zuari estuary, Goa, India from the estuarine mouth, Dona Paula (DP; $15^{\circ} 25^{\prime} 16.9^{\prime \prime} \mathrm{N}, 73^{\circ} 47^{\prime} 36.9^{\prime \prime} \mathrm{E}$ ), mid-estuary, Cortalim (CR; 15 $\left.24^{\prime} 32.0^{\prime \prime} \mathrm{N}, 73^{\circ} 54^{\prime} 50.2^{\prime \prime} \mathrm{E}\right)$ and upstream station, Sanvordem (SV; $15^{\circ} 16^{\prime} 01.1^{\prime \prime} \mathrm{N}$, $\left.74^{\circ} 06^{\prime} 36.0^{\prime \prime} \mathrm{E}\right)$. Similarly, surface-water samples were collected from Paradip port (area adjacent to fertilizer berths; $20^{\circ} 16^{\prime} 27.8^{\prime \prime} \mathrm{N}, 86^{\circ} 40^{\prime} 2.9^{\prime \prime} \mathrm{E}$ ) for saline water experiment (experiment II; salinity 29.4) and Kolkata port (tidal basin-1; $22^{\circ} 32^{\prime} 43^{\prime \prime} \mathrm{N}, 88^{\circ} 19^{\prime} 07^{\prime \prime} \mathrm{E}$ ) for freshwater experiment (experiment III; salinity 0.22) (Figure 1).

\section{Translocation and experimental set-up}

Port water $(\sim 201)$ collected from the three port environments was immediately incubated in dark for 30 days. Temperature during all three experiments was maintained between $25.0^{\circ} \mathrm{C}$ and $26.0^{\circ} \mathrm{C}$. All the experiments were conducted separately; Figure 2 provides a schematic representation of the experimental set-up.

Experiment I: Aged hypersaline water from Kandla port was translocated into the estuarine water of three different salinities in a ratio of $1: 5$ in 201 polycarbonate tanks (dimensions $43 \times 27 \times 18 \mathrm{~cm}$; Tarsons, Model no. 41080). The tanks were placed in static condition in the laboratory with natural light so as to provide natural daynight environment. The translocation of the aged port water into the water from the estuarine mouth (DP) is 


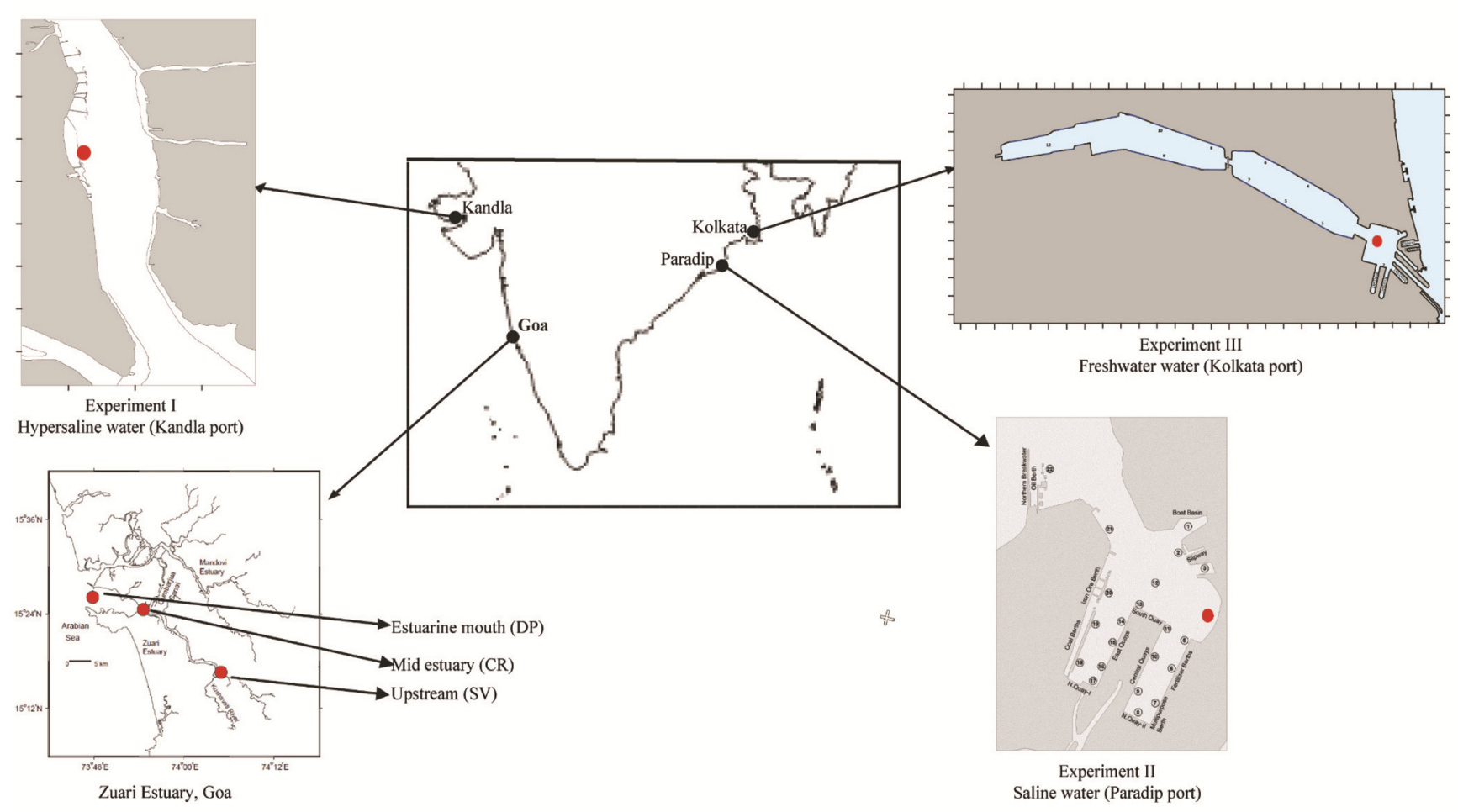

Figure 1. Location map showing the collection sites of water samples used in the experiment.

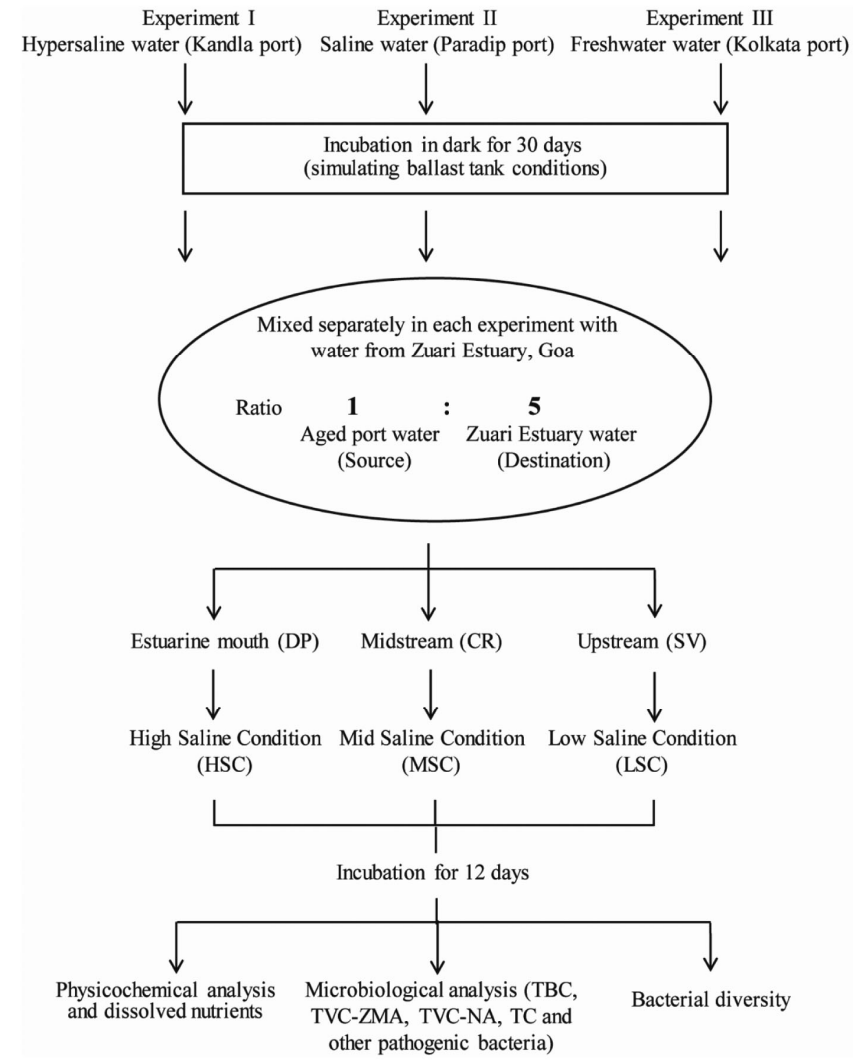

Figure 2. Schematic representation of experimental design. TBC, Total bacterial counts; TVC-ZMA, Total viable marine bacterial counts; TVC-NA, Total bacterial freshwater bacterial counts; TC, Total coliforms. henceforth referred to as high saline condition (HSC); the translocation of aged port water into water from the midestuarine station (CR) is termed as mid saline condition (MSC), and the translocation of the aged port water into water from the upstream station (SV) is henceforth termed as low saline condition (LSC). Incubation was conducted for each condition in duplicate tanks $(n=2)$ for 12 days.

The salinity of the aged Kandla port water was 39.38 , while it was 31.1, 13.51 and 0.03 at the mouth (DP), midestuary (CR) and upstream (SV) respectively. During the course of the experiment (after mixing), average salinity was $32.36 \pm 0.72$ in HSC, $15.28 \pm 0.35$ in MSC and $6.35 \pm 0.26$ in LSC.

Experiment II: Aged saline water from Paradip port was used for this experiment. The salinity of Paradip port water was 26.15 , while at DP, CR and SV it was 32.3, 18.57 and 0.05 respectively. After translocation, during the incubation period (12 days), the average salinity was $27.13 \pm 0.19,20.48 \pm 0.29$ and $4.54 \pm 0.06$ in HSC, MSC and LSC respectively.

Experiment III: Aged freshwater from Kolkata port was used for this experiment. Salinity at Kolkata port was 0.35 , whereas it was 34.49 at DP, 17.02 at CR and 0.14 at $\mathrm{SV}$. The average salinity after the mixing was $29.70 \pm$ 0.87 in HSC, $13.11 \pm 0.59$ in MSC and $0.13 \pm 0.01$ in LSC. 


\section{Physico-chemical analyses and dissolved nutrients}

Salinity measurements were done using an autosal (Guildline Autosal 8400B). For suspended particulate matter (SPM) measurements, $50 \mathrm{ml}$ of water samples was filtered through pre-weighed, pre-combusted $\left(400^{\circ} \mathrm{C}\right.$ for $\left.4 \mathrm{~h}\right)$, Whatman GF/F filter papers and dried in an oven for $48 \mathrm{~h}$ at $60^{\circ} \mathrm{C}$. Final weights were recorded as milligrams per litre $^{33}$. The dissolved oxygen (DO) was estimated using standard Winkler titration method ${ }^{34}$. Dissolved nutrients (silicate $\left(\mathrm{SiO}_{4}\right)$, phosphate $\left(\mathrm{PO}_{4}\right)$, nitrate $\left(\mathrm{NO}_{3}\right)$ and nitrite $\left(\mathrm{NO}_{2}\right)$ ) from the water samples were also analysed (Skalar SAN ${ }^{\text {PLUS }} 8505$ Interface v3.331, The Netherlands) ${ }^{35}$. Sodium hexafluoro silicate $\left(\mathrm{Na}_{2} \mathrm{SiF}_{6}\right)$, potassium dihydrogen phosphate $\left(\mathrm{KH}_{2} \mathrm{PO}_{4}\right)$, potassium nitrate $\left(\mathrm{KNO}_{3}\right)$ and sodium nitrite $\left(\mathrm{NaNO}_{2}\right)$ were used for the preparation of standards according to the manufacturer's guidelines for estimation of $\mathrm{SiO}_{4}, \mathrm{PO}_{4}, \mathrm{NO}_{3}$ and $\mathrm{NO}_{2}$ respectively.

\section{Microbiological analyses}

Samples for total bacterial count (TBC) were collected in duplicate $(n=2)$, preserved in $1 \%$ paraformaldehyde (final conc.) and kept at $-20^{\circ} \mathrm{C}$ until analysis. Samples were thawed before passing through a cell strainer cap (BD Biosciences, USA), stained with SYBR Green I (1:10,000 final conc.), and incubated in the dark condition for $15 \mathrm{~min}$. The stained samples were analysed on flow cytometer (BD FACS Verse) equipped with a blue laser of $488 \mathrm{~nm}$, using fluorescent beads ( $1 \mu \mathrm{m}$, Polyscience) as an internal standard ${ }^{36}$. The data were processed using BD FACS Diva software (BD Biosciences, USA) and expressed as cells per millilitre.

For total viable marine bacteria (TVC-ZMA) and total viable freshwater bacteria (TVC-NA), samples were appropriately diluted and spread on Zobell marine agar (ZMA, HiMedia) and nutrient agar (NA, HiMedia) respectively. Pathogenic bacteria were quantified on selective media according to the manufacturer's guidelines (HiMedia). Thiosulphate citrate bile salts (TCBS) agar was used for differentiating various Vibrio spp. ( $V$. parahaemolyticus (VP), $V$. alginolyticus (VA) and $V$. cholerae (VC)). MacConkey agar was used for enumeration of total coliforms (TC) and HiCrome EC O157:H7 agar was used for enumeration of Escherichia coli O157:H7. Identification of specific bacteria has been confirmed earlier using both biochemical tests and protein profiling through MALDI-TOF MS Biotyping ${ }^{35}$. The ZMA and NA agar plates were incubated at room temperature, while the selective media for pathogenic bacteria were incubated at $37^{\circ} \mathrm{C}$. Abundance was expressed as colony forming units per millilitre.

\section{Metagenomic bacterial diversity}

For metagenomic analysis, 1 litre of water sample collected from the tanks was filtered through $0.22 \mu \mathrm{m}$ pore size filter paper (Millipore, USA) by suction under low vacuum using a vacuum PR pump $(220 / 50 \mathrm{~Hz})$ connected to a filtration unit (PALL $47 \mathrm{~mm}$ ). The filter papers were kept at $-20^{\circ} \mathrm{C}$ until further processing. DNA extractions were performed using Power Water DNA isolation kit (MoBio lab. Geneworks, Australia). The DNA elutions were then diluted to $1: 100$ in autoclaved nuclease-free water $\left(\right.$ Ambion ${ }^{\mathrm{TM}}$ ) and quantified for an initial estimate of the concentration, which was $10-20 \mathrm{ng} \mathrm{ml}^{-1}$ (Qubit 2.0, Thermo Fisher Scientific, USA). Next, $1 \mu \mathrm{l}$ of the diluted samples was subjected to quantitative polymerase chain reaction (qPCR) using specific sets of primers for major bacterial phyla, namely Proteobacteria subclasses ( $\alpha, \beta$ and $\gamma$ ), Bacteroidetes, Firmicutes and Actinobacteria, to obtain the bacterial diversity as described in the literature ${ }^{37,38}$ (Table 1).

The qPCR assays were carried out on a real time PCR (Rotor-Gene Q; Qiagen). All the qPCR reactions were carried out in triplicates $(n=3)$. The PCR cocktail consisted of $10 \mu 12 x$ Power SYBR ${ }^{\circledR}$ Green PCR Master Mix (Applied Biosystems), $0.5 \mu \mathrm{l}$ each of the forward and reverse primers and $1 \mu \mathrm{l}$ of template, and made up to $20 \mu \mathrm{l}$ using nuclease-free water. The cycling conditions were initial enzyme activation at $95^{\circ} \mathrm{C}$ for $5 \mathrm{~min}, 45$ cycles of denaturation at $95^{\circ} \mathrm{C}$ for $1 \mathrm{~min}$, annealing at $53^{\circ} \mathrm{C}$ for $1 \mathrm{~min}$ and extension at $72^{\circ} \mathrm{C}$ for $1 \mathrm{~min}$. Tenfold dilutions of previously quantified target DNAs were used as internal standards. The amplification curves were obtained by plotting the threshold cycle $\left(C_{\mathrm{T}}\right)$ value against the logarithm of fluorescence. Furthermore, to check the efficiency of the reaction (which was always between 0.98 and 1.0), a melt curve analysis was performed after each designed run which confirmed that the fluorescence signals were obtained from the target amplicon. The unknown samples were quantified from their $C_{\mathrm{T}}$ values on the amplification curves using the Roton-Gene Q software (v 2.3.4).

\section{Graphical representation and statistical analyses}

All the graphical representations and illustrations were done using Grapher ${ }^{\mathrm{TM}}$ (Golden Software, LLC, $\mathrm{v} 12.3 .734)$. The relationship between abiotic ( $\mathrm{DO}, \mathrm{pH}$, SPM, TOC, $\mathrm{SiO}_{4}, \mathrm{PO}_{4}, \mathrm{NO}_{3}$ and $\mathrm{NO}_{2}$ ), and biotic (TBC, TVC-ZMA, TVC-NA and bacterial diversity) variables was evaluated using canonical correspondence analysis (CCA; CANOCO v4.5 for Windows software package) after log transformation, using Monte-Carlo test to assess the significance of the method $(P<0.05 ; 999$ permutations). Prior to the analyses, unimodal characteristics of the data were checked using detrended correspondence analysis (the length of the first axes were greater than 2 SD units $)^{39}$. CCA triplots were created to visualize the relationship between the abiotic and biotic parameters. The length and orientation of the arrows denote their relative influence on the biotic variables (Figure 3 ). Significant $(P \leq 0.05)$ environmental factors are denoted by 
Table 1. Primer sets for quantitative PCR used in the present study

\begin{tabular}{|c|c|c|c|c|}
\hline Target group & $\begin{array}{c}\text { Annealing } \\
\text { temperature }\left({ }^{\circ} \mathrm{C}\right)\end{array}$ & Primer & Sequence $\left(5^{\prime}-3^{\prime}\right)$ & Reference \\
\hline$\alpha$-Proteobacteria & 53 & $\begin{array}{l}\alpha-682 \mathrm{~F} \\
\alpha-908 \mathrm{R}\end{array}$ & $\begin{array}{l}\text { CIAGTGTAGAGGTGAAATT } \\
\text { CCCCGTCAATTCCTTTGAGTT }\end{array}$ & 37 \\
\hline$\beta$-Proteobacteria & 53 & $\begin{array}{l}\beta-359 \mathrm{~F} \\
\beta-682 \mathrm{R}\end{array}$ & $\begin{array}{l}\text { GGGGAATTTTGGACAATGGG } \\
\text { ACGCATTTCACTGCTACACG }\end{array}$ & 38 \\
\hline$\gamma$-Proteobacteria & 53 & $\begin{array}{l}\gamma-1080 \mathrm{~F} \\
\gamma-1202 \mathrm{R}\end{array}$ & $\begin{array}{l}\text { TCGTCAGCTCGTGTYGTGA } \\
\text { CGTAAGGGCCATGATG }\end{array}$ & 37 \\
\hline Bacteroidetes & 53 & $\begin{array}{l}798 \mathrm{cfbF} \\
\mathrm{cfb} 967 \mathrm{R}\end{array}$ & $\begin{array}{l}\text { CRAACAGGATTAGATACCCT } \\
\text { GGTAAGGTTCCTCGCGTAT }\end{array}$ & 37 \\
\hline Firmicutes & 53 & $\begin{array}{l}\text { 928FirmF } \\
\text { 1040FirmR }\end{array}$ & $\begin{array}{l}\text { TGAAACTYAAAGGAATTGACG } \\
\text { ACCATGCACCACCTGTC }\end{array}$ & 37 \\
\hline Actinobacteria & 53 & $\begin{array}{l}\text { Act920F3 } \\
\text { Act1200R }\end{array}$ & $\begin{array}{l}\text { TACGGCCGCAAGGCTA } \\
\text { TCRTCCCCACCTTCCTCCG }\end{array}$ & 37 \\
\hline
\end{tabular}

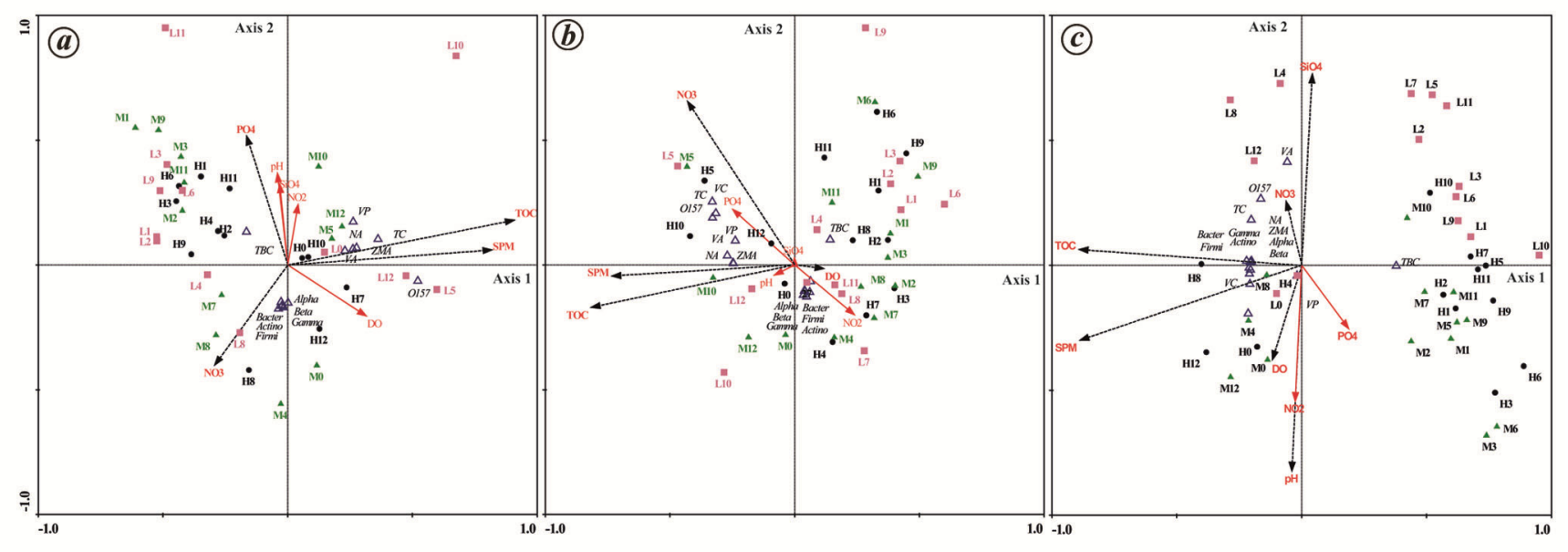

- H0- H12 High Saline Condition (HSC) Day 0- Day 12 A M0-M12 Mid Saline Condition (LSC) Day 0- Day 12 घ L0-L12 Low Saline Condition (LSC) Day 0- Day 12

Figure 3. Canonical correspondence analysis (CCA) showing the relationship between bacteria and environmental parameters in (a) experiment I (hypersaline port water experiment), (b) experiment II (saline port water experiment) and (c) experiment III (freshwater port water experiment). H0-H12 (filled black circles) denote incubation period of 12 days in HSC; M0-M12 (filled green triangles) denote incubation period of 12 days in MSC; L0-L12 (filled pink squares) denote incubation period of 12 days in LSC. Black lines indicate the various environmental parameters. Dotted black lines are highly significant (Monte Carlo test, $P<0.05$ ). The empty triangles indicate the species variables. DO, Dissolved oxygen; SPM, Suspended particulate matter; TOC, Total organic carbon; $\mathrm{SiO}_{4}$, Silicate; $\mathrm{PO}_{4}$, Phosphate; $\mathrm{NO}_{3}, \mathrm{Nitrate} \mathrm{NO}_{2}, \mathrm{Nitrite} ; \mathrm{O} 157$, Escherichia coli O157:H7; TC, Total coliforms; VA, Vibrio alginolyticus; VP, V. parahaemolyticus; VC, V. cholerae; Alpha, $\alpha$-proteobacteria; Beta $\beta$ proteobacteria; Gamma, $\gamma$-proteobacteria; Actino, Actinobacteria; Bacter, Bacteroidetes; Firmi, Firmicutes.

dashed lines. The correlations between biotic and abiotic parameters were further confirmed using STATISTICA (StatSoft, Inc. (2007); data analysis software system; version 8.0. (www.statsoft.com). Regression with $P$ value $\leq 0.05$ was considered significant and has been tabulated (Table 2).

\section{Results}

\section{Hypersaline port water experiment (experiment I)}

Table 3 provides the values of physico-chemical parameters and dissolved nutrient values in the aged port water and water from different stations of the estuary representing the mouth (DP), mid-estuary (CR) and upstream (SV) locations. After translocation, during the incubation period, SPM was lower than the aged port water due to addition of estuarine water with low SPM (Table 3), but increased during the incubation period and was $549 \pm 119,475 \pm 139$ and $537 \pm 277 \mathrm{mg} \mathrm{l}^{-1}$ in HSC, MSC and LSC respectively (Table 3). A similar trend was observed in TOC concentration. However, there was no significant change in phosphate concentration. Nitrate concentration decreased in all three conditions, whereas vice versa was observed in the case of nitrite concentration (Table 3).

Table 4 shows the values of TBC, TVC-ZMA, TVCNA and pathogenic bacteria in the aged port water, DP, $\mathrm{CR}$ and SV. During the incubation period, average TBC which was $6.9 \pm 0.7 \times 10^{7}$ cells $\mathrm{ml}^{-1}$ in the aged port 
Table 2. Correlation analysis between bacterial counts and physico-chemical parameters in high, mid and low saline conditions of experiments I-III

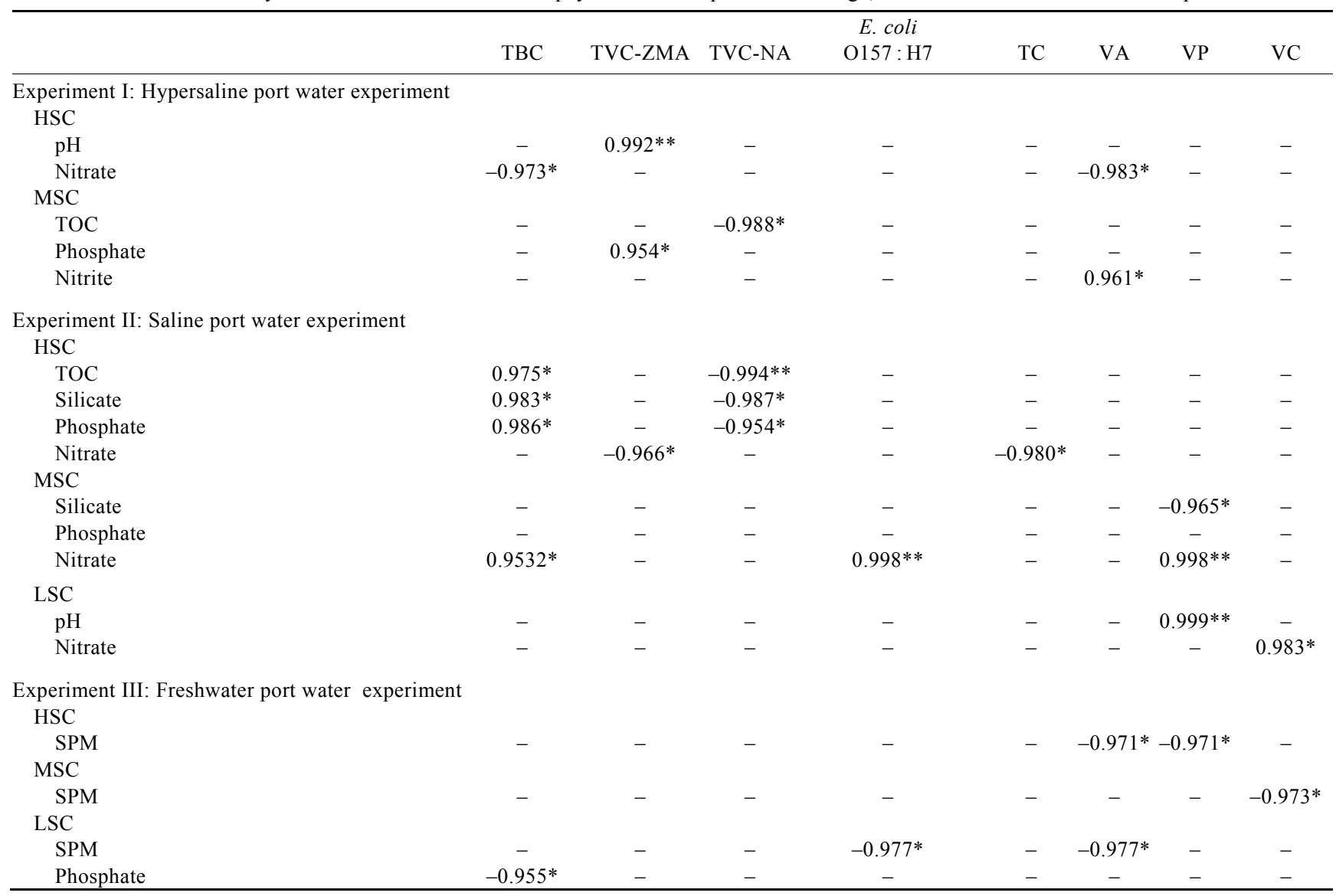

TBC, Total bacterial count; TVC-ZMA, Total viable marine bacteria; TVC-NA, Total viable freshwater bacteria; TC, Total coliforms; VA, Vibrio alginolyticus; VP, V. parahaemolyticus; VC, V. cholerae; ${ }^{*} P \leq 0.05 ;{ }^{*} P \leq 0.01$; '-' No significant correlation.

water decreased over time. Within the three conditions, TBC was high in HSC $\left(1.2 \pm 0.1 \times 10^{7}\right.$ cells $\left.\mathrm{ml}^{-1}\right)$ and showed a negative correlation with $\mathrm{NO}_{3}(r=-0.973)$. It was low in $\operatorname{LSC}\left(4.4 \pm 2.4 \times 10^{6}\right.$ cells $\left.\mathrm{ml}^{-1}\right)$. TBC was also positively influenced by $\mathrm{PO}_{4}$ (Figure $3 \mathrm{a}$ ). However, TVC-ZMA increased after the mixing and was high in HSC $\left(5.5 \pm 2.1 \times 10^{3} \mathrm{CFU} \mathrm{ml}^{-1}\right)$, whereas TVC-NA was high in $\operatorname{LSC}\left(28.9 \pm 18.1 \times 10^{3} \mathrm{CFU} \mathrm{ml}^{-1}\right.$; Table 4). E. coli $\mathrm{O} 157: \mathrm{H} 7$ was only detected in LSC, whereas Vibrio spp., preferred and increased in higher salinity. $V$. alginolyticus was high in $\mathrm{HSC}\left(393 \pm 459 \mathrm{CFU} \mathrm{ml}^{-1}\right)$ and V. parahaemolyticus was high in MSC $\left(95 \pm 123 \mathrm{CFU} \mathrm{ml}^{-1}\right.$; Table 4). VA showed a negative correlation with $\mathrm{NO}_{3}$ in HSC $(r=-0.983)$ and was positively influenced by $\mathrm{NO}_{2}$ in MSC ( $r=0.961$; Table 2). TOC and SPM were the key factors that positively influenced TVC-ZMA, TVC-NA and pathogenic bacteria (Figure $3 a$ ).

Before aging, the port water was dominated by Actinobacteria (53.64\%; Figure $4 a$ ). After aging, however, the bacterial diversity shifted in the aged port water with $\alpha$-proteobacteria (55.19\%) and Bacteroidetes (36.36\%) being the dominant phyla (Figure $4 b$ ). In the estuarine stations, bacterial diversity was dominated by $\beta$ - proteobacteria $(80.04 \%)$ at DP, $\alpha$-proteobacteria $(55.45 \%)$ at $\mathrm{CR}$ and $\gamma$-proteobacteria $(36.06 \%)$ and Bacteroidetes $(33.78 \%)$ at $\mathrm{SV}$ (Figure $4 c, d$ and $e$ ) respectively. After translocation, in HSC, the bacterial diversity was initially dominated by Bacteroidetes (63.47\%) followed by $\beta$-proteobacteria (19.67\%). However, there was a steady increase in Actinobacteria and $\gamma$-proteobacteria over time (Figure $4 f$ ). In MSC, however, bacterial diversity was dominated by $\alpha$-proteobacteria $(40.58 \%)$, but subsequently shifted to $\beta$-proteobacteria and Bacteroidetes (Figure $4 \mathrm{~g}$ ). The bacterial diversity at LSC was initially dominated by Actinobacteria, but a significant increase in Bacteroidetes during the later stages of incubation was evident (Figure $4 h$ ). Nitrate had a positive influence on all the major taxonomic phyla (Figure $3 a$ ).

\section{Saline port water experiment (experiment II)}

Table 5 shows the physico-chemical parameters and dissolved nutrient values in the aged port water, DP, CR and $\mathrm{SV}$. During the incubation period after translocation, SPM did not vary significantly in HSC and MSC but was low in $\operatorname{LSC}\left(79 \pm 13 \mathrm{mg} \mathrm{l}^{-1}\right)$, where it showed a decreasing 
RESEARCH ARTICLES

Table 3. Physico-chemical parameters and dissolved nutrients in hypersaline port water (source), aged hypersaline port water, estuarine stations (destination) and during incubation period after mixing in high saline condition (HSC), mid saline condition (MSC) and low saline condition (LSC) in experiment I

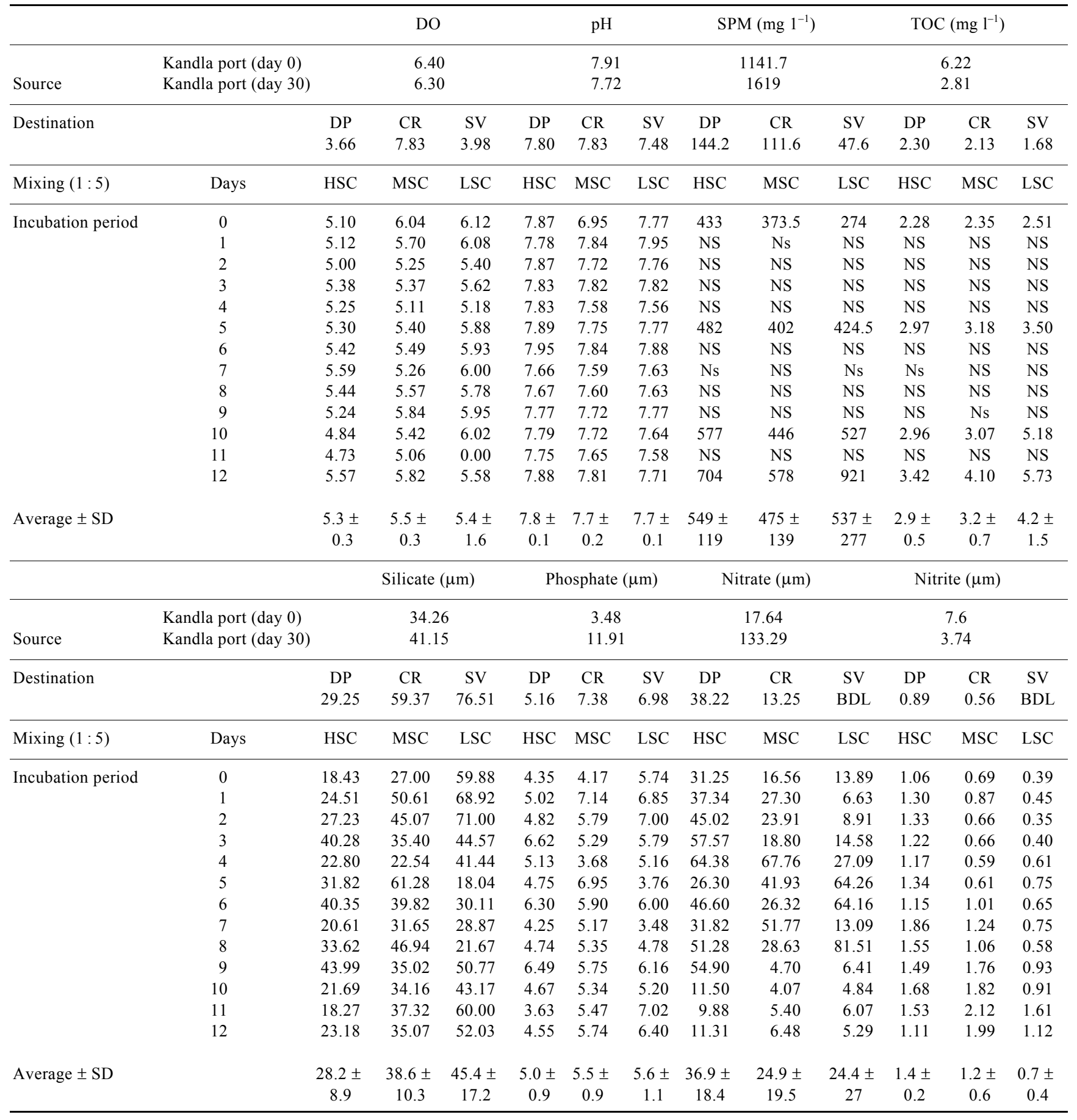

DP, Dona Paula (estuarine mouth station); CR, Cortalim (mid estuarine station); SV, Sanvordem (upstream station); DO, Dissolved oxygen; SPM, Suspended particulate matter; TOC, Total organic carbon; NS, Not sampled and BDL, Below detection limit.

trend (Table 5). TOC, however, showed an increasing trend under all conditions. There was a significant increase in $\mathrm{PO}_{4}$ concentration after five days of incubation. $\mathrm{NO}_{3}$ concentration was high in LSC $(7.4 \pm 9.4 \mu \mathrm{M})$, but decreased over time under all three conditions (Table 5).
Table 6 shows the bacterial abundance before translocation in the aged port water and estuarine locations. After translocation, TBC reduced by one order of magnitude. Under the three conditions, it was high in HSC $\left(3.3 \pm 0.7 \times 10^{6}\right.$ cells $\left.\mathrm{ml}^{-1}\right)$ and low in $\operatorname{LSC}(8.4 \pm$ 







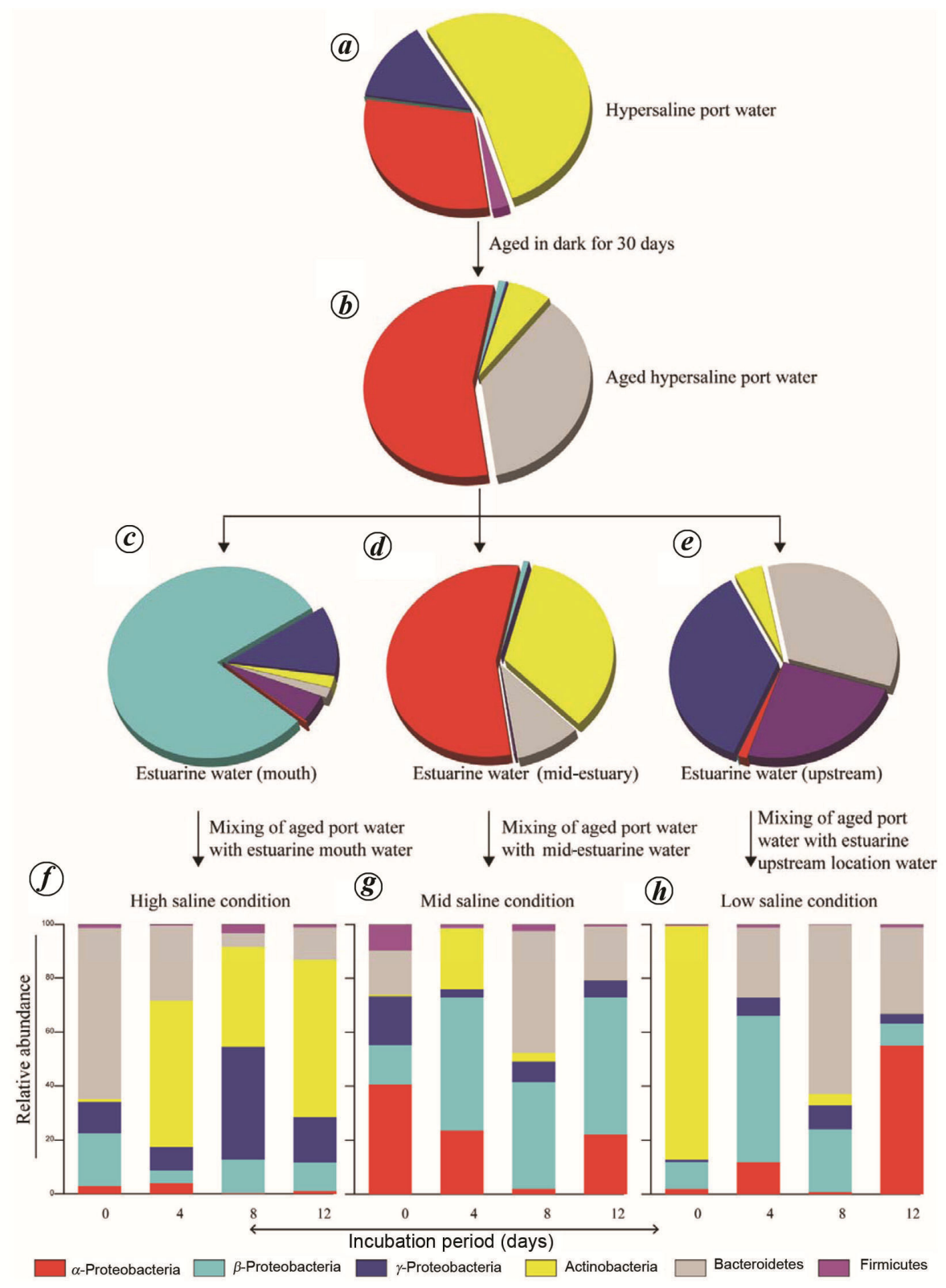

Figure 4. Relative abundance of gene copy numbers $\mu 1^{-1}$ in experiment I of $\alpha$-proteobacteria (red), $\beta$-proteobacteria (light blue), $\gamma$-proteobacteria (dark blue), Actinobacteria (yellow), Bacteroidetes (grey) and Firmicutes (purple) in (a) Hypersaline port water, (b) aged hypersaline port water, (c) water from estuarine mouth (DP), (d) mid-estuary (CR) and (e) estuarine upstream (SV). Relative abundance of major bacterial phyla during the incubation period after mixing in $(\boldsymbol{f})$ high saline condition (HSC), $(\boldsymbol{g})$ mid saline condition (MSC) and $(\boldsymbol{h})$ low saline condition (LSC).

$3.6 \times 10^{5}$ cells $\mathrm{ml}^{-1}$ ) during the incubation period. It was positively influenced by $\mathrm{PO}_{4}$ during $\mathrm{HSC}$, and by nitrate during MSC (Table 2), whereas SPM and TOC showed a negative correlation with TBC under all three conditions (Figure $3 b$ ). TVC-ZMA showed an increasing trend under all three conditions and was negatively correlated with nitrate in HSC, while TVC-NA were high in LSC (Table 6) and was negatively correlated with TOC, silicate and phosphate in HSC (Table 2). There was significant increase in E. coli $\mathrm{O} 157: \mathrm{H} 7$ abundance in LSC during the incubation period. However, both VA and VP were high in HSC $\left(2.5 \pm 3.3 \times 10^{3}\right.$ and $623 \pm 917 \mathrm{CFU}$ $\mathrm{ml}^{-1}$ respectively) (Table 6). VP showed a negative correlation with silicate and was positively influenced by nitrate in MSC (Table 2). A strong positive correlation was observed between nitrate and TVC-ZMA, TVC-NA and pathogenic bacteria (Figure $3 b$ ).

The Paradip port water bacterial diversity was initially dominated by $\alpha$-proteobacteria (75.74\%; Figure $5 a$ ). However, after aging, bacterial diversity in the aged port water was dominated by $\gamma$ - and $\beta$-proteobacteria $(52.63 \%$ and $29.72 \%$ respectively) (Figure $5 b$ ). In the estuarine stations, $\gamma$ - and $\alpha$-proteobacteria $(36.34 \%$ and $31.86 \%$ respectively) were dominant in DP, Actinobacteria and 
Table 5. Physico-chemical parameters and dissolved nutrients in saline port water (source), aged saline port water, estuarine stations (destination) and during incubation period after mixing in HSC, MSC and low LSC in experiment II

\begin{tabular}{|c|c|c|c|c|c|c|c|c|c|c|c|c|c|}
\hline & & \multicolumn{3}{|c|}{ DO } & \multicolumn{3}{|c|}{$\mathrm{pH}$} & \multicolumn{2}{|c|}{$\mathrm{SPM}\left(\mathrm{mg} \mathrm{1^{-1 } )}\right.$} & \multicolumn{4}{|c|}{ TOC $\left(\mathrm{mg} \mathrm{l}^{-1}\right)$} \\
\hline & \multicolumn{2}{|l|}{ Paradip port (day 0) } & \multicolumn{2}{|c|}{4.90} & \multicolumn{3}{|c|}{7.74} & \multicolumn{2}{|c|}{105.3} & \multicolumn{4}{|c|}{ NS } \\
\hline Source & \multicolumn{2}{|l|}{ Paradip port (day 30 ) } & \multicolumn{2}{|c|}{6.35} & \multicolumn{3}{|c|}{7.93} & \multicolumn{2}{|c|}{242} & \multicolumn{4}{|c|}{2.31} \\
\hline \multirow[t]{2}{*}{ Destination } & & DP & CR & SV & DP & CR & SV & $\mathrm{DP}$ & $\mathrm{CR}$ & SV & DP & CR & SV \\
\hline & & 4.44 & 4.09 & 4.44 & 7.89 & 7.78 & 7.67 & 218 & 216.5 & 223 & 2.56 & 2.83 & 4.03 \\
\hline Mixing (1:5) & Days & HSC & MSC & LSC & HSC & $\mathrm{MSC}$ & LSC & HSC & MSC & LSC & $\mathrm{HSC}$ & MSC & LSC \\
\hline \multirow[t]{12}{*}{ Incubation period } & 0 & 3.04 & 2.98 & 3.62 & 8.10 & 7.92 & 7.51 & 192.5 & 224.5 & 72 & 2.66 & 2.89 & 2.36 \\
\hline & 1 & 3.17 & 3.23 & 3.66 & 8.05 & 7.93 & 7.48 & NS & NS & NS & NS & NS & NS \\
\hline & 2 & 3.31 & 3.26 & 3.74 & 7.98 & 7.88 & 7.45 & NS & NS & NS & NS & NS & NS \\
\hline & 3 & 3.27 & 3.10 & 3.7 & 7.92 & 7.85 & 7.60 & NS & NS & NS & NS & NS & NS \\
\hline & 4 & NS & NS & NS & 7.94 & 7.82 & 7.55 & NS & NS & NS & NS & NS & NS \\
\hline & 5 & NS & NS & NS & 7.97 & 7.90 & 7.55 & 260.5 & 250 & 94.5 & 2.69 & 2.98 & 2.73 \\
\hline & 6 & 3.50 & 3.51 & 3.93 & 7.95 & 7.90 & 7.57 & NS & NS & NS & NS & NS & NS \\
\hline & 8 & NS & NS & NS & 8.01 & 7.96 & 7.39 & NS & NS & NS & Ns & NS & NS \\
\hline & 9 & 3.56 & 3.55 & 3.665 & 7.99 & 7.97 & 7.36 & NS & NS & NS & NS & NS & NS \\
\hline & 10 & NS & NS & NS & 7.98 & 7.97 & 7.51 & 234 & 253.5 & 82.5 & 3.71 & 3.72 & 2.84 \\
\hline & 11 & NS & & NS & NS & 8.01 & 8.01 & 7.52 & NS & NS & NS & NS & NS \\
\hline & 12 & 3.59 & 3.64 & 4.055 & 8.06 & 8.01 & 7.74 & 260.5 & 263.5 & 66.5 & 3.79 & 4.73 & 3.76 \\
\hline \multirow[t]{2}{*}{ Average $\pm \mathrm{SD}$} & & $\begin{array}{c}3.4 \pm \\
0.2\end{array}$ & $\begin{array}{c}3.3 \pm \\
0.3\end{array}$ & $\begin{array}{c}3.8 \pm \\
0.2\end{array}$ & $\begin{array}{l}8 \pm \\
0.1\end{array}$ & $\begin{array}{c}7.9 \pm \\
0.1\end{array}$ & $\begin{array}{c}7.5 \pm \\
0.1\end{array}$ & $\begin{array}{c}237 \pm \\
32\end{array}$ & $\begin{array}{c}248 \pm \\
17\end{array}$ & $\begin{array}{c}79 \pm \\
13\end{array}$ & $\begin{array}{c}3.2 \pm \\
0.6\end{array}$ & $\begin{array}{c}3.6 \pm \\
0.9\end{array}$ & $\begin{array}{c}2.9 \pm \\
0.6\end{array}$ \\
\hline & & & \multicolumn{2}{|c|}{ Silicate $(\mu \mathrm{m})$} & \multicolumn{3}{|c|}{ Phosphate $(\mu \mathrm{m})$} & \multicolumn{2}{|c|}{ Nitrate $(\mu \mathrm{m})$} & \multicolumn{4}{|c|}{ Nitrite $(\mu \mathrm{m})$} \\
\hline & \multirow{2}{*}{\multicolumn{2}{|c|}{$\begin{array}{l}\text { Paradip port (day } 0) \\
\text { Paradip port (day } 30 \text { ) }\end{array}$}} & 43.2 & & & 1.98 & & & 7.11 & & & 39 & \\
\hline Source & & & 16.9 & & & 3.54 & & & 1.03 & & & 95 & \\
\hline Destination & & $\mathrm{DP}$ & CR & SV & $\mathrm{DP}$ & $\mathrm{CR}$ & SV & $\mathrm{DP}$ & $\mathrm{CR}$ & SV & $\mathrm{DP}$ & $\mathrm{CR}$ & SV \\
\hline & & 6.31 & 6.94 & 49.39 & 2.75 & 11.93 & 9.06 & 3.82 & 1.08 & 6.50 & 1.25 & 0.75 & 0.44 \\
\hline Incubation period & 0 & 7.53 & 16.70 & 61.81 & 2.58 & 4.05 & 5.41 & BDL & 0.15 & 6.12 & 0.92 & 0.87 & 0.25 \\
\hline & 1 & 6.33 & 16.57 & 57.51 & 1.73 & 3.71 & 5.16 & BDL & BDL & 4.60 & 0.81 & 0.79 & 0.27 \\
\hline & 3 & 9.17 & 12.44 & 44.98 & 2.72 & 2.37 & 3.98 & 4.14 & 1.48 & 4.41 & 1.04 & 1.01 & 0.17 \\
\hline & 3 & 6.46 & 17.29 & 63.88 & 1.91 & 2.91 & 5.65 & 0.47 & 2.75 & 4.74 & 1.05 & 0.88 & 0.22 \\
\hline & 4 & 7.80 & 14.56 & 36.80 & 1.57 & 3.06 & 4.72 & 3.10 & 0.50 & 5.13 & 1.09 & 0.81 & 0.17 \\
\hline & 5 & 22.44 & 28.93 & 37.05 & 7.92 & 13.62 & 14.79 & 17.52 & 26.69 & 26.62 & 0.68 & 0.69 & 0.10 \\
\hline & 6 & 16.99 & 26.84 & 111.52 & 13.94 & 13.96 & 17.11 & 12.41 & 18.46 & 3.25 & 0.66 & 0.74 & 0.10 \\
\hline & 7 & 58.21 & 78.66 & 73.31 & 15.98 & 13.31 & 15.20 & BDL & BDL & EDI. & 0.67 & 0.68 & 0.15 \\
\hline & 8 & 53.93 & 55.74 & 59.21 & 16.94 & 17.43 & 10.54 & BDL & BDL & 1.33 & 0.42 & 0.53 & BDL \\
\hline & 9 & 44.72 & 61.28 & 70.77 & 13.42 & 14.11 & 14.11 & 0.37 & 0.39 & 27.64 & 0.44 & 0.47 & 0.05 \\
\hline & 10 & 48.85 & 82.10 & 48.86 & 15.10 & 13.56 & 10.45 & 0.71 & 1.03 & 0.74 & BDL & 0.14 & BDL \\
\hline & 11 & 31.46 & 26.99 & 34.42 & 11.41 & 14.89 & 13.37 & BDL & BDL & 0.80 & 0.26 & 0.35 & 0.11 \\
\hline & 12 & 54.58 & 66.49 & 35.03 & 14.34 & 15.37 & 15.24 & 1.67 & 1.88 & 2.84 & 0.47 & 0.58 & 0.13 \\
\hline Average \pm SD & & $\begin{array}{c}28.3 \pm \\
21\end{array}$ & $\begin{array}{c}38.8 \pm \\
26\end{array}$ & $\begin{array}{c}56.6 \pm \\
21.4\end{array}$ & $\begin{array}{c}9.2 \pm \\
6.2\end{array}$ & $\begin{array}{c}10.2 \pm \\
5.8\end{array}$ & $\begin{array}{c}10.4 \pm \\
4.9\end{array}$ & $\begin{array}{c}5.1 \pm \\
6.4\end{array}$ & $\begin{array}{c}5.9 \pm \\
9.7\end{array}$ & $\begin{array}{c}7.4 \pm \\
9.4\end{array}$ & $\begin{array}{c}0.7 \pm \\
0.3\end{array}$ & $\begin{array}{c}0.7 \pm \\
0.2\end{array}$ & $\begin{array}{c}0.2 \pm \\
0.1\end{array}$ \\
\hline
\end{tabular}

$\gamma$-proteobacteria $(49.78 \%$ and $36.28 \%$ respectively) in CR and $\beta$-proteobacteria in SV (51.26\%) (Figure $5 c, d$ and $e$ respectively). After translocation, bacterial diversity was initially dominated by $\alpha$-proteobacteria $(76.73 \%)$ in HSC. However, Bacteroidetes (78.11\%) were abundant by day 4 of incubation. There was a steady increase in $\beta$ - and $\gamma$ proteobacteria throughout the incubation period, which eventually dominated the bacterial diversity along with
Actinobacteria (Figure $5 f$ ). In MSC, $\gamma$-proteobacteria (78.65\%) were dominant while $\beta$-proteobacteria showed a steady increase, eventually dominating the bacterial diversity (Figure $5 \mathrm{~g}$ ). In LSC, bacterial diversity was initially dominated by Bacteroidetes $(52.9 \%)$ and $\gamma$-proteobacteria (38.59\%). Similar to MSC, $\beta$-proteobacteria increased significantly and dominated bacterial diversity $(73.46 \%)$ by the end of the incubation period (Figure $5 \mathrm{~h}$ ). 


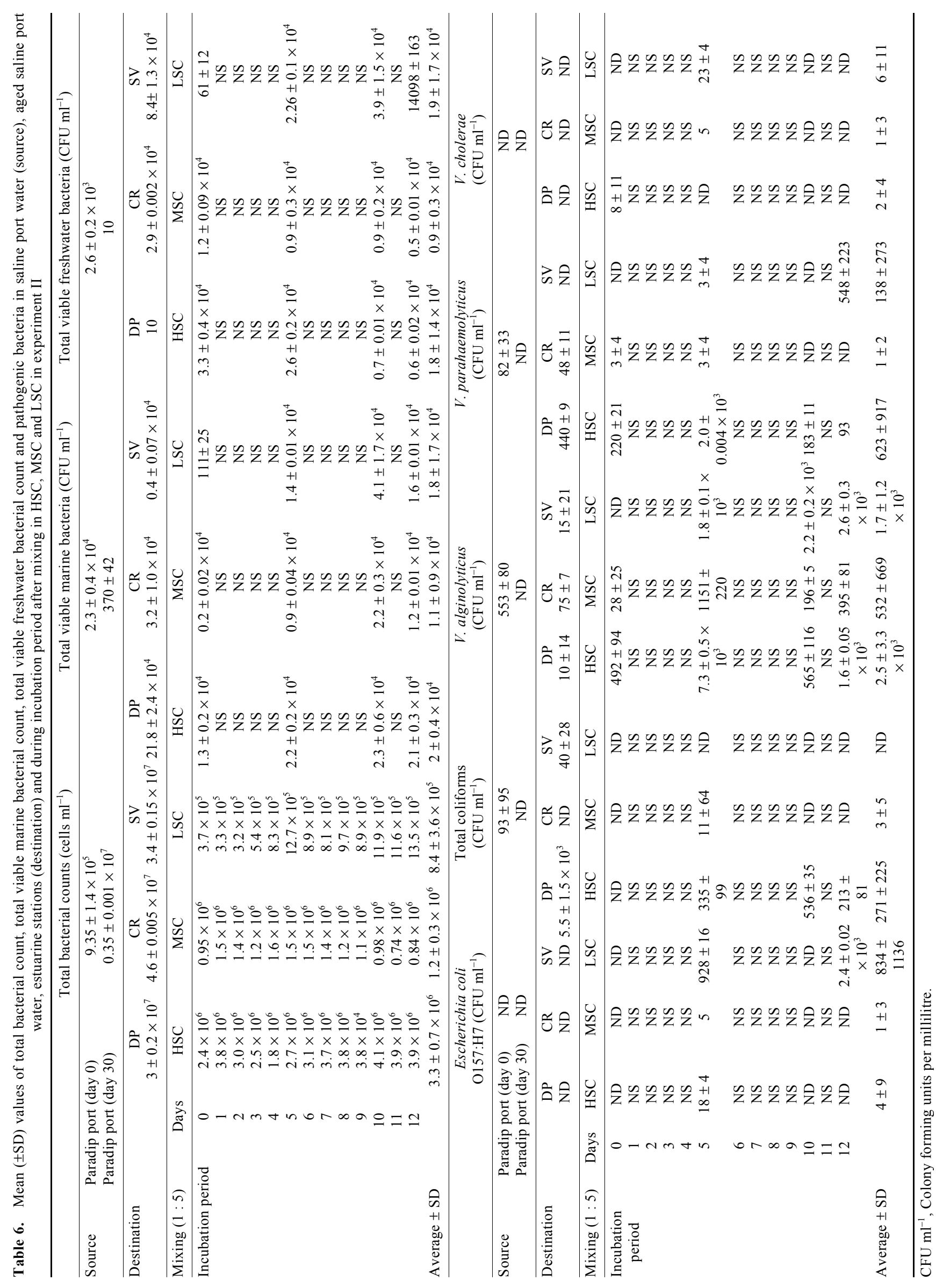

CURRENT SCIENCE, VOL. 119, NO. 3, 10 AUGUST 2020 

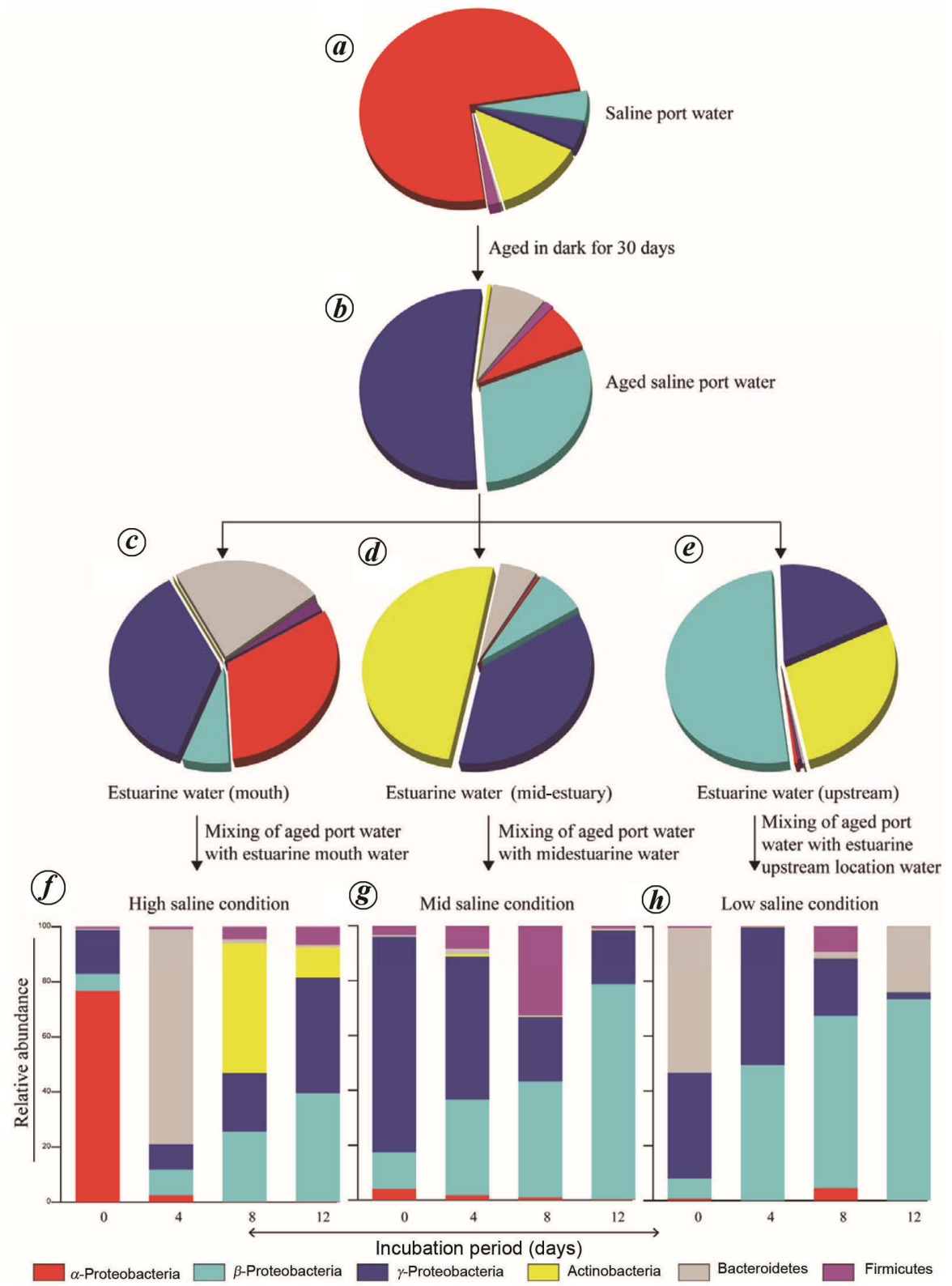

Figure 5. Relative abundance of gene copy numbers $\mu 1^{-1}$ in experiment II of $\alpha$-proteobacteria (red), $\beta$-proteobacteria (light blue), $\gamma$-proteobacteria (dark blue), Actinobacteria (yellow), Bacteroidetes (grey) and Firmicutes (purple) in $(\boldsymbol{a})$ saline port water, $(\boldsymbol{b})$ aged saline port water, $(\boldsymbol{c})$ water from estuarine mouth (DP), $(\boldsymbol{d})$ mid-estuary (CR) and $(\boldsymbol{e})$ estuarine upstream (SV). Relative abundance of major bacterial phyla during the incubation period after mixing in $(\boldsymbol{f}) \mathrm{HSC},(\boldsymbol{g}) \mathrm{MSC}$ and $(\boldsymbol{h})$ LSC.

\section{Freshwater port water experiment (experiment III)}

Table 7 shows the physico-chemical and dissolved nutrient values during freshwater port water experiment. After translocation during the incubation period, SPM which was $199 \mathrm{mg} \mathrm{l}^{-1}$ increased significantly under all the conditions and was $403 \pm 55,299 \pm 108$ and $213 \pm 33 \mathrm{mg} \mathrm{l}^{-1}$ in HSC, MSC and LSC respectively. TOC increased significantly and was high in LSC $\left(4.6 \pm 1.8 \mathrm{mg} \mathrm{l}^{-1}\right)$ (Table 7). $\mathrm{NO}_{3}$ concentration was particularly high in the aged port water $(82.59 \mu \mathrm{M})$ before translocation and was high in MSC $(23.9 \pm 5 \mu \mathrm{M})$ and $\operatorname{LSC}(23.8 \pm 3 \mu \mathrm{M})$ during the incubation period after translocation (Table 7).
Table 8 shows the bacterial abundance in the aged port water and estuarine stations before translocation. After translocation, TBC reduced by one order of magnitude and was high in $\operatorname{HSC}\left(2.5 \pm 0.7 \times 10^{6}\right.$ cells ml $\left.^{-1}\right)$ and low in $\operatorname{LSC}\left(2.3 \pm 0.6 \times 10^{6}\right.$ cells ml $\left.\mathrm{m}^{-1}\right)$. However, it increased over time under all conditions during the incubation period. SPM and TOC showed a negative correlation with TBC under all three conditions (Figure $3 c$ ). There was a significant increase in both TVC-ZMA and TVC-NA, which were high in $\operatorname{HSC}\left(1.1 \pm 1 \times 10^{4} \mathrm{CFU} \mathrm{ml}^{-1}\right.$ and $3.5 \pm 4 \times 10^{3} \mathrm{CFU} \mathrm{\textrm {ml } ^ { - 1 }}$ respectively) during the incubation period. Also, E. coli $\mathrm{O} 157: \mathrm{H} 7$ and TC thrived in lower salinities and showed a weak positive correlation 
RESEARCH ARTICLES

Table 7. Physico-chemical parameters and dissolved nutrients in freshwater port water (source), aged freshwater port water, estuarine stations (destination) and during incubation period after mixing in HSC, MSC and LSC in experiment III

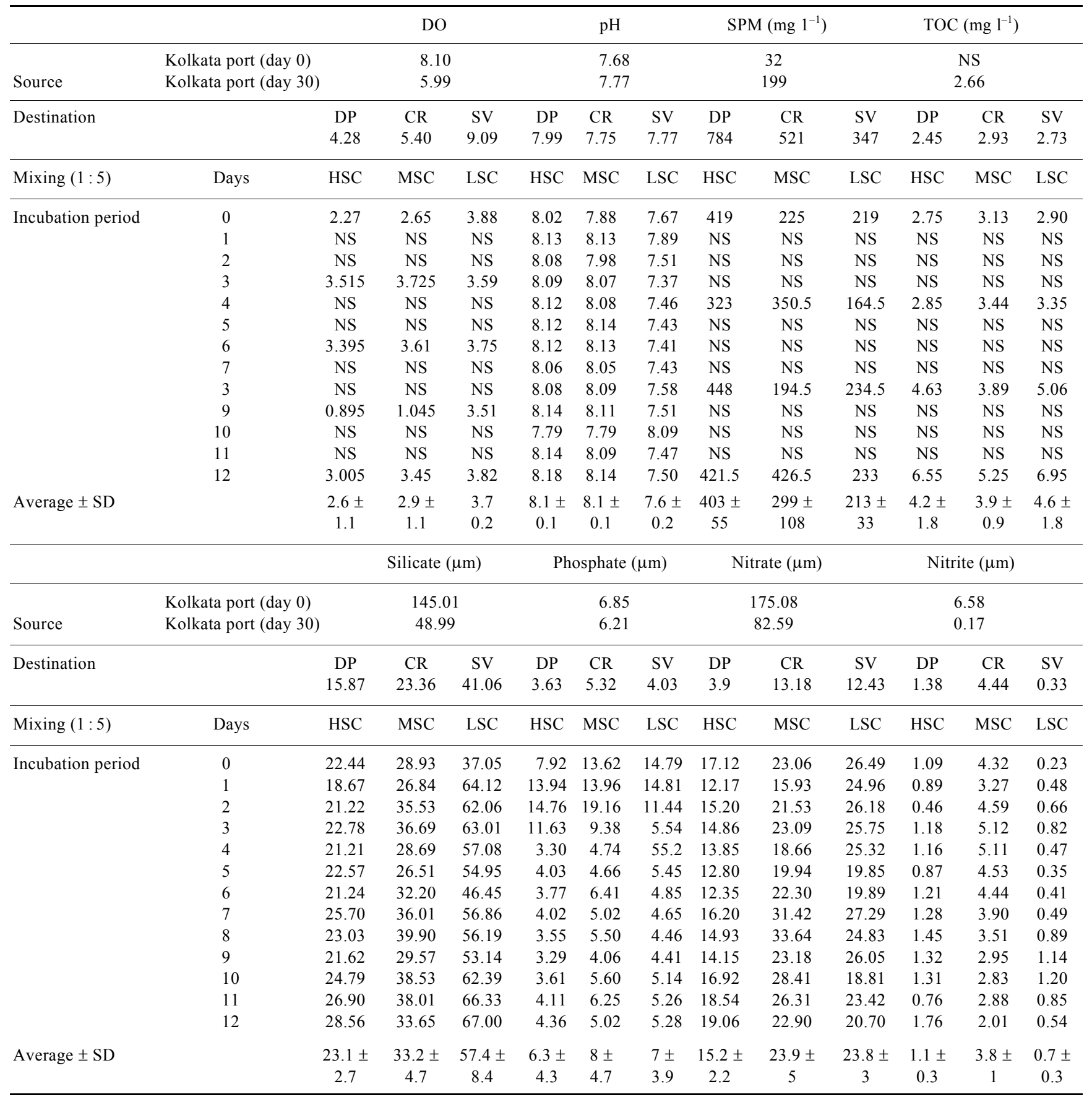

with $\mathrm{NO}_{3}$ (Figure $3 c$ ). VA was also high in LSC, whereas VP and VC were high in HSC (Table 8). A negative correlation between SPM and VA during LSC was observed (Table 2), whereas VC showed a positive correlation with SPM (Figure $3 c$ ).

The Kolkata port water bacterial diversity was initially dominated by Actinobacteria (59.96\%) (Figure $6 a$ ). After aging, bacterial diversity in the aged port water was dominated by Bacteroidetes (72.06\%) (Figure $6 b$ ), while in the estuarine stations bacterial diversity in DP and CR was dominated by Bacteroidetes (62.24\% and $75.44 \%$ respectively) and by $\gamma$-proteobacteria in SV (67.92\%) (Figure $6 c, d$ and $e$ respectively). During the incubation period, $\gamma$-proteobacteria $(75.62 \%)$ were dominant in HSC, while a steady increase in $\alpha$ - and $\beta$-proteobacteria was observed over time. Firmicutes, in HSC, did not vary significantly during the whole course of the experiment $(\sim 13.5 \%)$ (Figure $6 f)$. In MSC, bacterial diversity was also dominated by $\gamma$-proteobacteria $(71.75 \%)$ initially, but decreased subsequently with an increase in the abundance of $\alpha$-proteobacteria $(41.09 \%)$ and Bacteroidetes $(34.58 \%)$, which dominated bacterial diversity by the end of the 


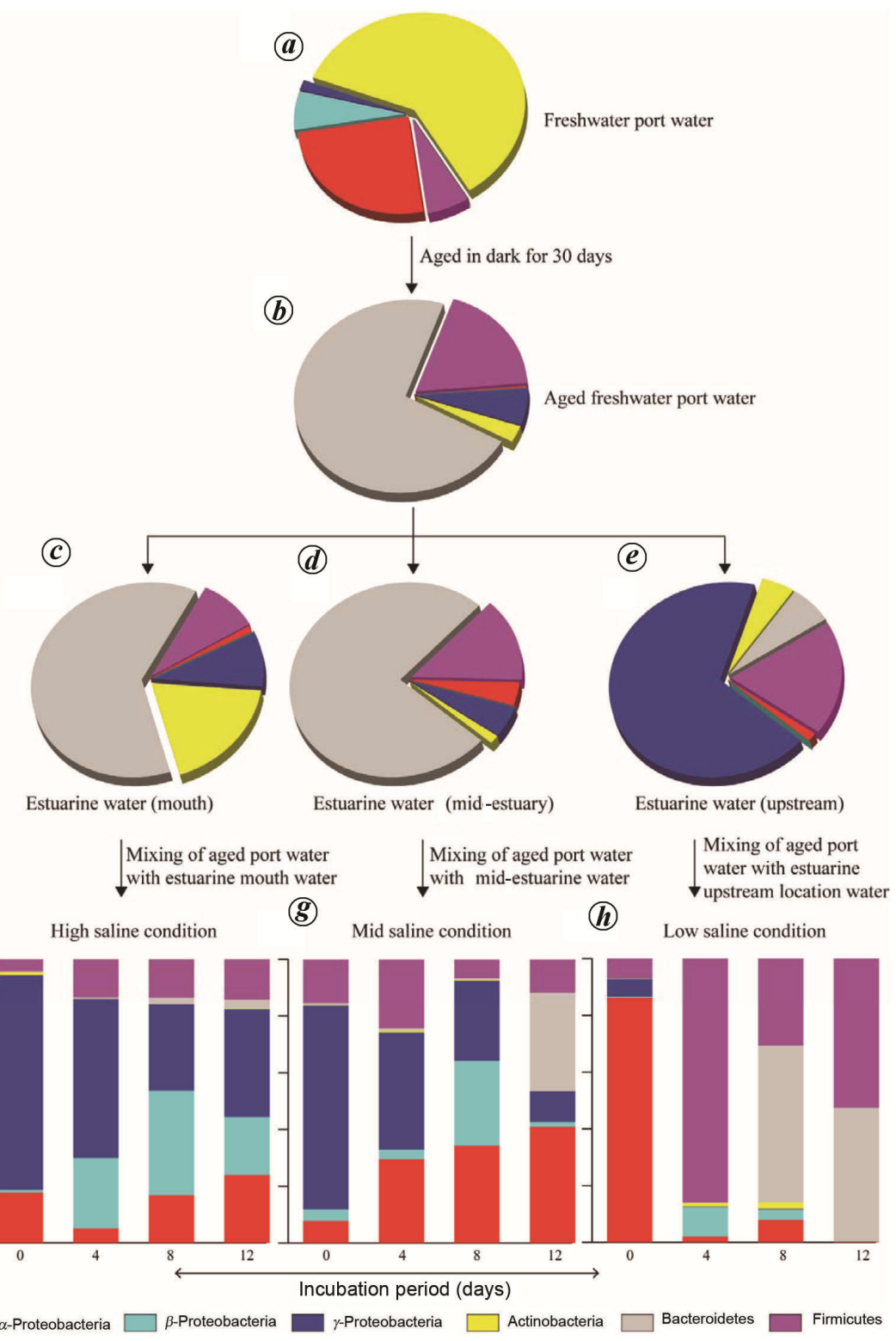

Figure 6. Relative abundance of gene copy numbers $\mu 1^{-1}$ in experiment III of $\alpha$-proteobacteria (red), $\beta$-proteobacteria (light blue), $\gamma$-proteobacteria (dark blue), Actinobacteria (yellow), Bacteroidetes (grey) and Firmicutes (purple) in (a) freshwater port water, (b) aged freshwater port water, $(\boldsymbol{c})$ water from estuarine mouth (DP), $(\boldsymbol{d})$ mid-estuary (CR) and $(\boldsymbol{e})$ estuarine upstream (SV). Relative abundance of major bacterial phyla during the incubation period after mixing in $(\boldsymbol{f}) \mathrm{HSC},(\boldsymbol{g}) \mathrm{MSC}$ and $(\boldsymbol{h})$ LSC.

incubation period (Figure $6 \mathrm{~g}$ ). In LSC, $\alpha$-proteobacteria $(86.23 \%)$ were dominant initially after translocation. However, it was later dominated by Firmicutes and Bacteroidetes (Figure $6 h$ ). TOC had a positive influence on Bacteroidetes, Firmicutes, Actinobacteria, and $\beta$ proteobacteria, whereas $\alpha$ - and $\gamma$-proteobacteria were positively influenced by SPM (Figure $3 c$ ).

\section{Discussion}

The present study mimics the process of BW discharge using microcosm experiments. The aging of port water in dark simulated the conditions in the BW tanks during a voyage. Previous studies have reported that BWE is effective during longer duration voyages (15 days to several months $)^{40}$. In this study, aging of the port water in dark for 30 days resulted in a shift in bacterial diversity with an increase in bacterial clades better adapted to stress. The study was conducted using qPCR, which has been widely utilized to assess bacterial diversity by overcoming the disadvantages of standard culture techniques, thus including the viable but not culturable (VBNC) segment of bacteria.

\section{Hypersaline port water experiment (experiment I)}

The aging of port water in dark resulted in a decrease in $\mathrm{TBC}$, and also a shift in bacterial diversity from 


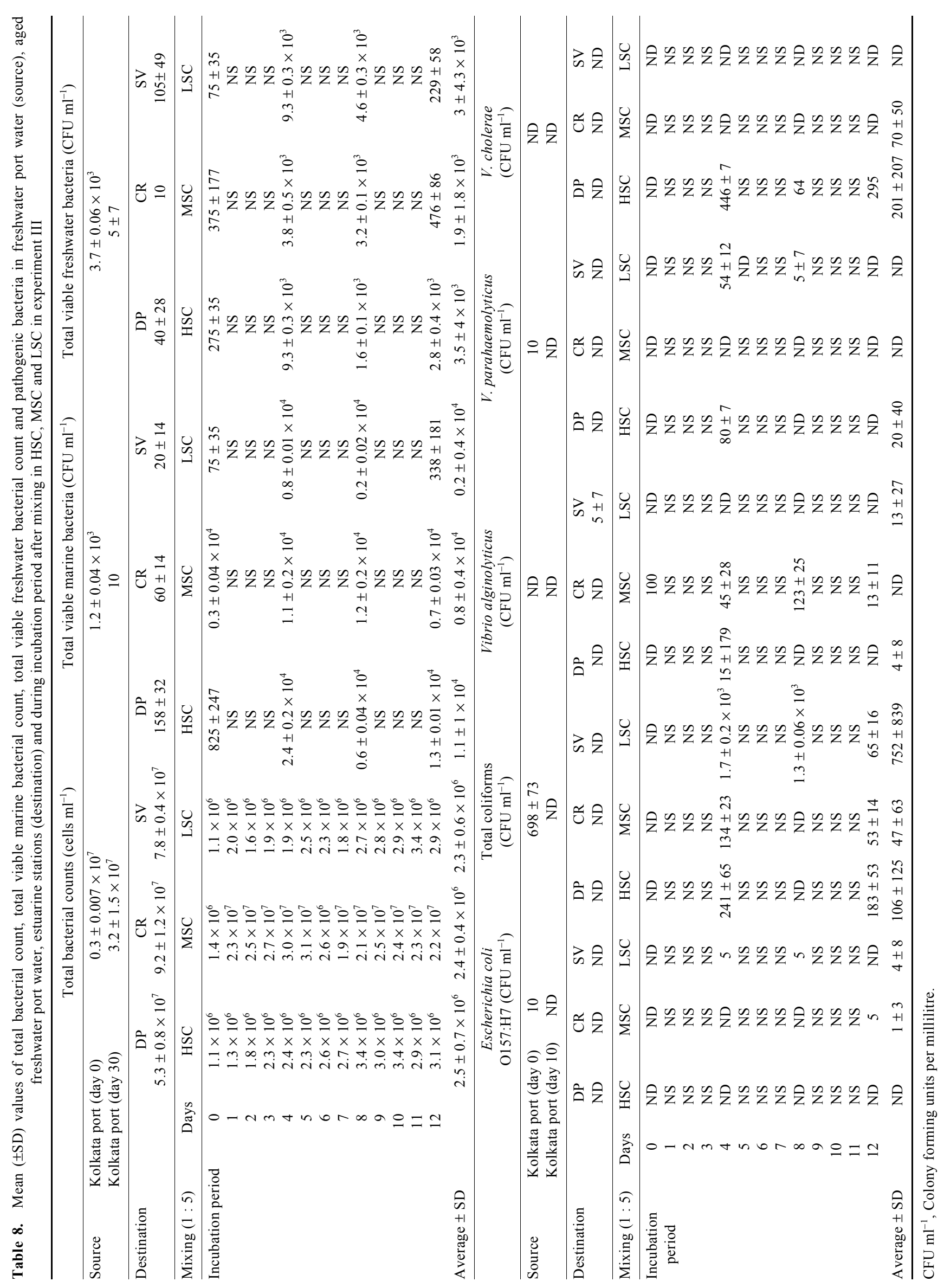

CURRENT SCIENCE, VOL. 119, NO. 3, 10 AUGUST 2020 
Actinobacteria to $\alpha$-proteobacteria, which are known to grow in aphotic deep ocean areas ${ }^{41}$. TBC in this aged hypersaline port water when translocated to the estuarine mouth (DP), mid-estuary (CR) and upstream (SV), preferred HSC, which could be due to higher stress on the bacteria when the aged port water was translocated to lower salinity estuarine water. However, after the initial shock following translocation, TBC continued to increase throughout the incubation period under all the three conditions. In addition to TBC, VA and $\gamma$-proteobacteria also preferred higher salinity where low $\mathrm{NO}_{3}$ concentrations were detected and $\mathrm{NO}_{2}$ concentrations showed an increasing trend. $\gamma$-Proteobacteria (which include VA) have been known to play a major role in nitrate reduction in marine systems ${ }^{42}$, which could have led to the reduction of $\mathrm{NO}_{3}$ to $\mathrm{NO}_{2}$. Most of the viable bacteria, including the pathogenic strains (VA, VP and TC) were positively influenced by SPM. The influence of SPM on both autochthonous and allochthonous bacteria has already been illustrated ${ }^{36}$. SPM not only provides important nutrients, but also harbours attached bacteria that contribute to bacterial diversity. Additionally, it provides protection from UV radiation and predation, which is beneficial when such organisms are discharged into a new environment from BW tanks. Bacteria attached to the SPM are metabolically more active and are more resistant to environmental changes ${ }^{43}$. Hence, SPM can influence the bacterial load (especially pathogens) and also aid in their survival during stressed conditions in the aquatic systems.

The bacterial diversity changed significantly over time under all three conditions. $\gamma$-Proteobacteria preferred high salinity, whereas $\beta$-proteobacteria were dominant in the mid-saline range. This is in congruence with a similar study on biofilm bacteria from coastal port environments ${ }^{44}$, and a similar pattern was observed in another study along a salinity gradient in Zuari estuary ${ }^{45}$. They were positively influenced by $\mathrm{NO}_{3}$ but negatively by $\mathrm{PO}_{4}$ concentrations (low in HSC). A study reported that many phosphate solubilizing bacteria (PSB) belong to Firmicutes and $\beta$-proteobacteria ${ }^{46}$, which were dominant in the lower salinity conditions (MSC and LSC). It is possible that PSB were low in HSC due to which the $\mathrm{PO}_{4}$ concentrations were low in that condition. Additionally, most pathogenic groups belong to $\gamma$-proteobacteria, whose contribution to the bacterial diversity in LSC was minimal. Although they were present in the upstream location (SV), the addition of hypersaline port water could have led to additional stress on the prevailing bacterial diversity, which could not cope with the stress after translocation. On the other hand, Firmicutes were high in LSC, which play an important role in organic matter turnover due to their enzyme secretion capacity ${ }^{47}$. The bacterial diversity was not only different in different saline conditions, but the response of certain phyla to salinity stress was also different. Hence, the response of the aged bacterial taxa from ballast tanks when exchanged in the open ocean during BWE will depend to a great extent on the source of the BW and its ability to tackle salinity stress. In the present study, when aged water from the hypersaline port was translocated into low saline water from the estuary (LSC), the change in bacterial diversity was significant. This was expected since the change in salinity is highest in LSC.

\section{Saline port water experiment (experiment II)}

As a result of aging in the dark, TBC increased and bacterial diversity also showed a distinct change where the dominance shifted from $\alpha$-proteobacteria to $\gamma$-proteobacteria. When the aged saline port water was translocated into the water from DP, CR, and SV, the resultant salinity changed, especially in LSC (aged saline port water translocated to water from upstream location), leading to a significant decrease in TBC. However, both viable marine (TVC-ZMA) and freshwater (TVC-NA) bacteria persisted upon change in salinity after translocation. Similar to the trend observed in experiment I, TVCZMA were high in HSC. Whereas TVC-NA were high in LSC and were negatively correlated with $\mathrm{PO}_{4}$ and TOC. However, interestingly in LSC, although TVC-NA were high, there was no significant decline in TVC-ZMA. The marine bacteria in the aged saline port water could cope with the stress caused by the change in salinity. Vibrio spp. were higher than other pathogenic strains under all the three conditions. Additionally, $\gamma$-proteobacteria, which include Vibrio sp., were also prevalent under all the conditions. The versatility and adaptability of Vibrio sp. is well documented as they are euryhaline. In fact, toxicogenic $V$. cholerae are known to survive under a wide range of salinity ${ }^{32}$. They could not only be freeliving, but also plankton- and particulate matter-attached. Pathogenic bacteria are known to be associated with plankton $^{35}$, which protects them from predator feeding and harsh environmental changes.

The bacterial diversity in HSC was initially dominated by $\alpha$-proteobacteria and Bacteroidetes; however, with increase in incubation time after translocation, $\beta-\gamma$ proteobacteria and Actinobacteria dominated the bacterial diversity. Similarly, bacterial diversity in lower salinity ranges (MSC and LSC) were dominated by $\beta$ - and $\gamma$ proteobacteria. This increase in $\beta$-proteobacteria was accompanied by a significant increase in $\mathrm{PO}_{4}$ concentration. The role of $\beta$-proteobacteria in phosphate solubilization is well documented ${ }^{46}$, and was evident in both salinity conditions where they could dominate bacterial diversity. They were distinctly different from those of hypersaline water. Proteobacteria in this experiment showed a weak negative correlation with $\mathrm{NO}_{3}$ and were positively influenced by $\mathrm{NO}_{2}$. Proteobacteria are known to play an important role in dissimilatory nitrate reduction $^{48} . \mathrm{NO}_{3}$ concentrations were comparatively less, which stresses the importance of nitrate reducers in 
determining the community structure in response to environmental stress. Under favourable conditions, such mechanisms provide the bacteria additional leverage to establish and colonize a non-indigenous environment disrupting the local ecosystem.

\section{Freshwater port water experiment (experiment III)}

The aging of port water resulted in the shift of bacterial diversity from Actinobacteria to Bacteroidetes (known to degrade complex organic matter) and Firmicutes (known for spore-forming ability), in addition to an increase in TBC. The translocation of this aged freshwater port water showed significantly contrasting results when compared to marine port water experiments. TVC-NA from the aged freshwater port water, unlike those from the previous experiments (aged hypersaline and aged saline port water), were high at higher salinities. Port ecosystems are different from other coastal ecosystems given the high intensity of anthropogenic perturbations. The shipping activities and in turn the BW uptake and discharge are high in port areas. Moreover, Kolkata port is a freshwater port unlike the hypersaline Kandla and saline Paradip ports. It receives continuous inputs from the Hooghly River ${ }^{49}$, and bacterial diversity from the freshwater port ecosystem was able to resist salinity stress better than that of the hypersaline and saline ports. Hence, freshwater bacteria from Kolkata port seem to withstand translocation into HSC. Additionally, Vibrio spp. were not observed in the aged port water and the estuarine stations, except for VA in the upstream estuarine station. However, after translocation, they were observed under all three conditions, especially HSC. Adaptation of Vibrio spp. to high salt concentration has increased their chances of survival under environmental stress ${ }^{50}$. Vibrio spp. are euryhaline and are able to cope with salinity shock during translocation experiment. They are known to be stable for long periods of time in $\mathrm{BW}$ tanks, although their viability might decrease once introduced to new environments ${ }^{32}$. The bacteria could have been in a dormant condition until translocation into a suitable environment and under favourable conditions, they have a direct impact on human health.

The bacterial diversity in aged port water was dominated by Bacteroidetes (Figure $6 b$ ). These can be found in diverse marine habitats, including coastal and offshore waters. They are one of the most abundant bacterial phyla in coastal ecosystems aided by their ability to degrade complex organic matter ${ }^{51}$. But the translocation into estuarine water has revealed that Proteobacteria were more resilient to salinity change and hence were dominant after translocation. HSC was dominated by $\beta$ - and $\gamma$ proteobacteria, whereas $\alpha$ - and $\gamma$-proteobacteria were dominant in mid-saline range. Although a similar pattern in their distribution was observed in hypersaline and saline water bacterial diversities, the influence of distinctly different environmental factors could be due to the presence of region-specific proteobacterial clades. In lower salinity, however, Firmicutes and Bacteroidetes were dominant. Firmicutes are generally not considered to be marine organisms ${ }^{47}$; hence they flourished in LSC. Additionally, the contribution of Bacteroidetes to bacterial diversity in upstream location (SV) was minimal; so the contribution of this phylum to the bacterial diversity in LSC could be majorly from the port water and it showed a strong positive correlation with TOC. Since this phylum is known for its ability to degrade complex organic matter ${ }^{51}$, high TOC may have aided in its proliferation.

Coliforms (TC and E. coli $\mathrm{O} 157: \mathrm{H} 7$ ) were observed in LSC and generally preferred lower salinity. Coliforms are allochthonous and are less tolerant to salinity change. They are known to proliferate in $\mathrm{LSC}^{52}$. Rapid salinity change could cause cell inactivation ${ }^{53}$. However, they were detected in higher salinity ranges in all three experiments. It seems that even with the reduced culturability, they could reach a resting stage and proliferate under suitable conditions. Studies have also reported an increase in antibiotic resistance of pathogenic bacteria during incubation in $\mathrm{BW}$ tanks ${ }^{10}$.

\section{Bacterial community response to salinity stress}

The $\beta$ - and $\gamma$-proteobacteria from aged hypersaline port water (experiment I) preferred high to mid saline condition after translocation (HSC and MSC), whereas $\alpha$-proteobacteria preferred LSC. However, in the aged saline port water experiment (experiment II), $\beta$-and $\gamma$ proteobacteria preferred mid to low salinity conditions (MSC and LSC) after translocation. The $\beta$ - and $\gamma$-proteobacteria in aged freshwater port water (experiment III) preferred HSC, whereas $\alpha$-proteobacteria preferred MSC. No confirmed relationship can be established for the abundance of $\beta$ - and $\gamma$-proteobacteria in response to salinity stress. Each phylum proliferated under different salinity conditions in all three experiments. Additionally, bacterial diversity in each experiment was influenced by different physico-chemical factors. Despite their ubiquity, the species comprising these phyla could be different and occupy a highly specific niche in each geographical location and the species composition could be region-specific, which could explain the different responses to salinity stress in each experiment. Additionally, CCA triplots showed a grouping of all the major phyla comprising bacterial diversity. This could mean that instead of each individual bacterial clade reacting to environmental stress after translocation, they tackle the stress as a community.

The environmental factors affecting the microbiota were also different. Hence, the composition of bacterial community was driven by environmental settings. The 
dispersal and bioinvasive potential of these microbes may be influenced by environmental factors, which is in accordance with the Baas Becking hypothesis which states that 'everything is everywhere, but the environment selects'. Since the introduction of bacteria into a new environment in comparison to higher organisms is difficult to study, it is important to identify the key environmental factors that could aid in the establishment of non-indigenous bacteria. Although salinity is a critical parameter in determining bacterial diversity at a given location, the cumulative effect of other factors, in particular, nutrient dynamics could play a major role in determining bacterial diversity, which could be useful in devising BW treatment mechanisms that could prove better than BWE.

\section{Conclusion}

The aging of port waters (hypersaline, saline and freshwater) in dark condition resulted in a shift in bacterial diversity. Although there was a change in bacterial diversity in all three experiments after translocation, due to initial salinity shock, the resultant bacterial diversity after prolonged incubation withstood salinity stress over time. But the effect of the salinity stress was distinctly different among the bacterial phyla, which allowed the proliferation of a few bacterial clades well-equipped to withstand stress. The bacterial diversity of freshwater port could withstand salinity stress better than that from the hypersaline or saline ports. In freshwater port water, Bacteroidetes which are known to degrade a wide range of organic matter proliferated after the aging. Further, when this aged port water bacterial diversity was translocated into estuarine water with different salinities, the initial osmotic stress resulted in a shift in bacterial diversity with $\alpha$ - and $\gamma$-proteobacteria as the dominant species. However, after prolonged incubation, Bacteroidetes and Firmicutes (which includes members with specific endospore forming capability) proliferated in the lower salinities, whereas $\gamma$-Proteobacteria generally preferred higher salinity.

Thus, the risk of bioinvasion and the extent of success or failure of the introduced bacteria do not solely depend on the source of BW (hypersaline, saline and freshwater), but also on the environmental conditions, ecological health and resident biota of the recipient coastal port. This also holds true in terms of BWE, where the efficacy does not depend only on the source of BW but also on environmental settings at the point of BWE. It would be interesting to study the changes in bacterial diversity and their response to environmental stress during a voyage, which could provide an understanding of the invasive potential of the BW tank microbiota. Additionally, understanding the effects of the introduction of such resilient bacterial clades into the port environment through real- time observations would provide valuable insights into the risk of marine bioinvasion.

1. Elçiçek, H., Parlak, A. and Cakmakcı, M., Effect of ballast water on marine and coastal ecology. J. Selcuk. Univ. Nat. Appl. Sci., 2013, 1, 454-463.

2. Sun, B., Mouland, R., Way, C. and Rivkin, R. B., Redistribution of heterotrophic prokaryotes through ballast water: a case study from the west coast of Canada. Aquat. Invasions, 2010, 5, 5-11.

3. Raaymakers, S., The ballast water problem: global ecological, economic and human health impacts. In RECSO/IMO Joint Seminar on Tanker Ballast Water Management and Technologies, Dubai, UAE, 2002, pp. 16-18.

4. Anil, A. C. et al., Marine bioinvasion: concern for ecology and shipping. Curr. Sci., 2002, 83, 214-218.

5. Carlton, T. J., Transoceanic and interoceanic dispersal of coastal marine organisms : the biology of ballast. Oceanogr. Mar. Biol., 1985, 23, 313-371.

6. Cariton, J. T. and Geller, J. B., Ecological roulette: the global transport of nonindigenous marine organisms. Science, 1993, 261, $78-82$.

7. Cohen, A., Ships' ballast water and the introduction of exotic organisms into the San Francisco Estuary: current status of the problem and options for management. San Francisco Estuary Institute, Richmond CA, USA, 1998, p. 84.

8. Ducklow, W. H. and Shiah, F. K., Estuarine bacterial production. Aquat. Microbiol. - Ecol. Approach, 1993, 261-264.

9. Burkholder, J. A. M. et al., Phytoplankton and bacterial assemblages in ballast water of US military ships as a function of port of origin, voyage time, and ocean exchange practices. Harmful Algae, 2007, 6, 486-518.

10. Altug, G., Gurun, S., Cardak, M., Ciftci, P. S. and Kalkan, S., The occurrence of pathogenic bacteria in some ships' ballast water incoming from various marine regions to the Sea of Marmara, Turkey. Mar. Environ. Res., 2012, 81, 35-42.

11. Drake, L. A., Ruiz, G. M., Galil, B. S., Mullady, T. L., Friedmann, D. O. and Dobbs, F. C., Microbial ecology of ballast water during a transoceanic voyage and the effects of open-ocean exchange. Mar. Ecol. Prog. Ser., 2002, 233, 13-20.

12. Drake, L. A., Doblin, M. A. and Dobbs, F. C., Potential microbial bioinvasions via ships' ballast water, sediment, and biofilm. Mar. Pollut. Bull., 2007, 55, 333-341.

13. Ruiz, G. M. et al., Global spread of microorganisms by ships. Nature, 2000, 408, 49-50.

14. McCarthy, S. A. and Khambaty, F. M., International dissemination of epidemic Vibrio cholerae by cargo ship ballast and other nonpotable waters. Appl. Environ. Microbiol., 1994, 60, 2597-2601.

15. Colwell, R. R., Global climate and infectious disease: the cholera paradigm. Science, 1996, 274(5295), 2025-2031.

16. Lobitz, B. et al., Climate and infectious disease: use of remote sensing for detection of Vibrio cholerae by indirect measurement. Proc. Natl. Acad. Sci. USA, 2000, 97, 1438-1443.

17. Bailey, S. A., An overview of thirty years of research on ballast water as a vector for aquatic invasive species to freshwater and marine environments. Aquat. Ecosyst. Health Manage., 2015, 18, 261-268.

18. Lymperopoulou, D. S. and Dobbs, F. C., Bacterial diversity in ships' ballast water, ballast-water exchange, and implications for ship-mediated dispersal of microorganisms. Environ. Sci. Technol., 2017, 51, 1962-1972.

19. Wade, S. A., Stemming the tide: a plea for new exotic species legislation. J. Land Use Environ. Law, 1994, 10, 343.

20. McCollin, T., Shanks, A. M. and Dunn, J., The efficiency of regional ballast water exchange: changes in phytoplankton abundance and diversity. Harmful Algae, 2007, 6, 531-546. 
21. Gray, D. K., Johengen, T. H., Reid, D. F. and MacIsaac, H. J., Efficacy of open-ocean ballast water exchange as a means of preventing invertebrate invasions between freshwater ports. Limnol. Oceanogr., 2007, 52, 2386-2397.

22. Choi, K. H., Kimmerer, W., Smith, G., Ruiz, G. M. and Lion, K., Post-exchange zooplankton in ballast water of ships entering the San Francisco estuary. J. Plankton Res., 2005, 27, 707-714.

23. Dickman, M. and Zhang, F., Mid-ocean exchange of container vessel ballast water. 2: Effects of vessel type in the transport of diatoms and dinoflagellates from Manzanillo, Mexico, to Hong Kong, China. Mar. Ecol. Prog. Ser., 1999. 176, 253-262.

24. Leichsenring, J. and Lawrence, J., Effect of mid-oceanic ballast water exchange on virus-like particle abundance during two transPacific voyages. Mar. Pollut. Bull., 2011, 62, 1103-1108.

25. Seiden, J. M., Way, C. J. and Rivkin, R. B., Bacterial dynamics in ballast water during trans-oceanic voyages of bulk carriers: environmental controls. Mar. Ecol. Prog. Ser., 2011, 436, 145-159.

26. Molina, V. and Drake, L. A., Efficacy of open-ocean ballast water exchange: a review. Manage. Biol. Invasions, 2016, 7, 375-388.

27. Tomaru, A., Kawachi, M., Demura, M. and Fukuyo, Y., Denaturing gradient gel electrophoresis shows that bacterial communities change with mid-ocean ballast water exchange. Mar. Pollut. Bull., 2010, 60, 299-302.

28. Desai, D. V., Narale, D., Khandeparker, L. and Anil, A. C., Potential ballast water transfer of organisms from the west to the east coast of India: insights through on-board sampling. J. Sea Res., 2018, 133, 88-99.

29. Wang, J. et al., Do patterns of bacterial diversity along salinity gradients differ from those observed for macroorganisms? PLoS ONE, 2011, 6(11), e27597.

30. Tomaru, A., Kawachi, M., Demura, M. and Fukuyo, Y., Changes in microbial communities, including both uncultured and culturable bacteria, with mid-ocean ballast-water exchange during a voyage from Japan to Australia. PLoS ONE, 2014, 9(5), e96274.

31. Methé, B. A., Hiorns, W. D. and Zehr, J. P., Contrasts between marine and freshwater bacterial community composition: analyses of communities in Lake George and six other Adirondack lakes. Limnol. Oceanogr., 1998, 43, 368-374.

32. McCarthy, S. A., Effects of temperature and salinity on survival of toxigenic Vibrio cholerae O1 in seawater. Microb. Ecol., 1996, 31, 167-175.

33. Kumar, S., Ramesh, R., Bhosle, N. B., Sardesai, S. and Sheshshayee, M. S., Natural isotopic composition of nitrogen in suspended particulate matter in the Bay of Bengal. Biogeosciences, 2004, 1, 63-70.

34. Parsons, T. R., Maita, Y. and Lalli, C. M., A Manual of Chemical and Biological Methods for Seawater Analysis, Oxford, Pergamon Press, 1984, p. 173.

35. Khandeparker, L., Anil, A. C., Naik, S. D. and Gaonkar, C. C., Daily variations in pathogenic bacterial populations in a monsoon influenced tropical environment. Mar. Pollut. Bull., 2015, 96, 337-343.

36. Khandeparker, L. et al., Elucidation of the tidal influence on bacterial populations in a monsoon influenced estuary through simultaneous observations. Environ. Monit. Assess., 2017, 29, 41.

37. Bacchetti De Gregoris, T., Aldred, N., Clare, A. S. and Burgess, J. G., Improvement of phylum- and class-specific primers for realtime PCR quantification of bacterial taxa. J. Microbiol. Methods, 2011, 86, 351-356.

38. Ashelford, K. E., Weightman, A. J. and Fry, J. C., PRIMROSE: a computer program for generating and estimating the phylogenetic range of $16 \mathrm{~S}$ rRNA oligonucleotide probes and primers in conjunction with the RDP-II database. Nucleic Acids Res., 2002, 30, 3481-3489.
39. terBraak J. F. C. and Šmilauer, P., Canoco Reference Manual and CanoDraw for Windows User's Guide, Software for Canonical Community Ordination (version 4.5), 2002, p. 500.

40. Van Der Meer, R., Ballast water risk assessment in the North Sea. Evaluating ballast water management exemption in the North Sea region, 2012, vol. 44, no. 6, pp. 547-568.

41. Orcutt, B. N., Sylvan, J. B., Knab, N. J. and Edwards, K. J., Microbial ecology of the dark ocean above, at, and below the seafloor. Microbiol. Mol. Biol. Rev., 2011, 75, 361-422.

42. Philippot, L., Tracking nitrate reducers and denitrifiers in the environment. Biochem. Soc. Trans., 2005, 33, 200-204.

43. Iriberri, J., Unanue, M., Barcina, I. and Egea, L., Seasonal variation in population density and heterotrophic activity of attached and free-living bacteria in coastal waters. Appl. Environ. Microbiol., 1987, 53, 2308-23014.

44. Hede, N. and Khandeparker, L., Influence of darkness and aging on marine and freshwater biofilm microbial communities using microcosm experiments. Microb. Ecol., 2018, 76, 314-327.

45. Eswaran, R. and Khandeparker, L., Seasonal variation in bacterial community composition and $\beta$-glucosidase expression in a tropical monsoon-influenced estuary. Aquat. Microb. Ecol., 2017, 80, 273287.

46. Shuo, H., Dongliang, X. and Lubin, L., Diversity of the phosphate solubilizing bacteria isolated from the root of Phyllostachyspubescens. J. Agric. Hebei Univ., 2010, 33(2), 26-31.

47. Yilmaz, P., Yarza, P., Rapp, J. Z. and Glöckner, F. O., Expanding the world of marine bacterial and archaeal clades. Front. Microbiol., 2016, 6, 1-29.

48. Bru, D., Sarr, A. and Philippot, L., Relative abundances of proteobacterial membrane-bound and periplasmic nitrate reductases in selected environments. Appl. Environ. Microbiol., 2007, 73, 59715974.

49. Sinha, P. C. et al., Modeling of circulation and salinity in Hooghly Estuary. Mar. Geod., 1996, 19, 197-213; https://doi.org/10.1080/ 01490419609388079 .

50. Kalburge, S. S., Whitaker, W. B. and Boyd, E. F., High-salt preadaptation of Vibrio parahaemolyticus enhances survival in response to lethal environmental stresses. J. Food Prot., 2014, 77, 246-253.

51. González, J. M. et al., Genome analysis of the proteorhodopsincontaining marine bacterium Polaribactersp. MED152 (Flavobacteria). Proc. Natl. Acad. Sci. USA, 2008, 105, 8724-8729.

52. Karbasdehi, V. N. et al., Indicator bacteria community in seawater and coastal sediment: the Persian Gulf as a case. J. Environ. Health Sci. Eng., 2017, 15(1), 6.

53. Hughes, K. A., Influence of seasonal environmental variables on the distribution of presumptive fecal coliforms around an Antarctic research station. Appl. Environ. Microbiol., 2003, 69, 4884-4891.

ACKNOWLEDGEMENTS. We thank the Director, CSIR-National Institute of Oceanography (NIO), Goa, India for support and encouragement, and Dr Dattesh Desai (NIO), for support during this work. N.K. acknowledges CSIR, New Delhi for the award of Senior Research Fellowship. This work was funded by the Ballast Water Management Programme, India (Ministry of Shipping, Government of India and Director General of Shipping; GAP 2429) and CSIR-funded Ocean Finder Programme (PSC 0105). This is an NIO contribution no. 6517.

Received 14 January 2020; revised accepted 13 March 2020

doi: $10.18520 / \mathrm{cs} / \mathrm{v} 119 / \mathrm{i} 3 / 507-525$ 